\title{
The importance of grazing food chain for energy flow and production in three intertidal sand bottom communities of the northern Wadden Sea
}

\author{
Harald Asmus \& Ragnhild Asmus \\ Biologische Anstalt Helgoland (Litoralstation); D-2282 List/Sylt, \\ Federal Republic of Germany
}

\begin{abstract}
In three intertidal sand bottom communities of the "Königshafen" (Island of Sylt, North Sea), the biomass production and respiration of phytobenthos, phytoplankton, macrozoobenthos, and in situ community metabolism were measured monthly during 1980 . The study sites were characterized by different communities (Nereis-Corophium-belt, seagrass-bed, Arenicola-flat) and by a high abundance of the mollusc Hydrobia ulvae. Benthic diatoms are the major constituents of plant biomass in the Arenicola-flat. In this community, gross primary productivity amounts to $148 \mathrm{~g}$ $\mathrm{C} \mathrm{m}^{-2} \mathrm{a}^{-1} .82 \%$ of this productivity is caused by microbenthos, whereas phytoplankton constitutes only $18 \%$. In the seagrass-bed, gross primary productivity amounts to $473 \mathrm{~g} \mathrm{C} \mathrm{m}^{-2} \mathrm{a}^{-1} .79 \%$ of this is generated by seagrass and its epiphytes, whereas microphytobenthos contributes $19 \%$. In the Nereis-Corophium-belt, only microphytobenthos is important for biomass and primary productivity (gross: $152 \mathrm{~g} \mathrm{C} \mathrm{m}^{-2} \mathrm{a}^{-1}$ ). Annual production of macrofauna proved to be similar in the Arenicola* flat $\left(30 \mathrm{~g} \mathrm{C} \mathrm{m}^{-2} \mathrm{a}^{-1}\right)$ to that in the seagrass-bed $\left(29 \mathrm{~g} \mathrm{C} \mathrm{m}^{-2} \mathrm{a}^{-1}\right)$. Only one third of this amount is produced in the Nereis-Corophium-belt $\left(10 \mathrm{~g} \mathrm{C} \mathrm{m}^{-2} \mathrm{a}^{-1}\right)$. The main part of secondary production and animal respiration is contributed by grazing $H$. ulvae. In the seagrass-bed, $83 \%$ of the energy used for production is obtained from the grazing food chain. In the Arenicola-flat and the NereisCorophium-belt, the importance of non-grazing species is greater. A synchrony of seasonal development of plant biomass and monthly secondary production was observed. In the Arenicolaflat and the seagrass-bed, where density and production of macrofauna are high, a conspicuous decrease in biomass of microbenthos occurs during the warmer season, whereas in the NereisCorophium-belt primary production causes an increase in microphytobenthic biomass in summer and autumn. Energy flow through the macrofauna amounts to $69 \mathrm{~g} \mathrm{C} \mathrm{m}^{-2} \mathrm{a}^{-1}$ in the Arenicola-flat, $85 \mathrm{~g} \mathrm{C} \mathrm{m}^{-2} \mathrm{a}^{-1}$ in the seagrass-bed and $35 \mathrm{~g} \mathrm{C} \mathrm{m}^{-2} \mathrm{a}^{-1}$ in the Nereis-Corophium-beit. Based on the assumption that sources of food are used in proportion to their availability, $49 \mathrm{~g} \mathrm{C} \mathrm{m}^{-2} \mathrm{a}^{-1}$ (Arenicola-flat), $72 \mathrm{~g} \mathrm{C} \mathrm{m}^{-2} \mathrm{a}^{-1}$ (seagrass-bed) and $26 \mathrm{~g} \mathrm{C} \mathrm{m}^{-2} \mathrm{a}^{-1}$ (Nereis-Corophium-belt) are estimated as taken up by the grazing food chain. All three subsystems are able to support the energy requirements from their own primary production and are not dependent on energy import from adjacent ecosystems.
\end{abstract}

\section{INTRODUCTION}

Intense biological activity is a prominent feature of intertidal areas. Tidal flats are exposed to high light intensity due to low water depth and the periodic emerging of the sediment. Additionally, nutrients are abundant; thus, tidal flats meet the requirements for high primary production. Accordingly, benthic secondary production is enhanced which is indicated by the great biomass of benthic macrofauna.

Long-term measurements of intertidal primary production of phytoplankton and 
microphytobenthos have been conducted chiefly in the Dutch Wadden Sea (Postma \& Rommets, 1970; Cadée \& Hegeman, 1974 a,b, 1979; Cadée, 1980; Gieskes \& Kraay, 1975; Colijn \& de Jonge, 1984). Based upon these findings, it was postulated that autochthonous primary production is relatively low and that it only insufficiently explains the richness and high production of the fauna (Van den Hoek et al., 1979; Kuipers et al., 1981). These authors suppose that the input of phytoplankton and detritus from the North Sea builds the main source of food in the Wadden Sea ecosystem.

Macrofauna, rich in biomass, constitutes an important link between primary producers and consumers of higher levels. Macrofauna must necessarily be highly productive in order to maintain the high values of biomass that are found in the Wadden Sea in spite of strong predation by numerous birds, fishes and invertebrates. Measurements of secondary production in intertidal areas reveal values similar to those in subtidal areas (Beukema, 1981; Warwick \& Price, 1975). Although the structure of macrofauna has been investigated intensively in the German Wadden Sea, investigations on secondary production are missing. But measurements of secondary production are not sufficient in order to characterize the function of macrofauna in the ecosystem. Energy flow through macrofauna cannot be measured directly, whereas production and respiration of macrofauna can be measured. The latter are the two main constituents of energy flow, which is the sum of both.

Simultaneous measurements of secondary production and respiration were performed by studying single populations in order to obtain evidence of their total energy budget (Hughes, 1970; Kuenzler, 1961; Odum \& Smalley, 1959; Teal, 1962; Mann, 1965). The importance of the respiration of macrofauna species could be proved (Hargrave, 1971; Mathias, 1971; Paine, 1971; Miller \& Mann, 1973; Kofoed, 1975) and much attention has been paid to respiration of consumers in connexion with energy flow of whole communities (Jansson \& Wulff, 1977; Pamatmat, 1968, 1977; Hargrave, 1969; Banse et al., 1971).

It is necessary for the understanding of the Wadden Sea ecosystem to go beyond measurements of isolated components and to combine measurements of primary and secondary production in order to ascertain the interactions of different parameters. This is possible using the bell jar technique (Zeitzschel \& Davies, 1978; Zeitzschel, 1981). Measurements of community metabolism were conducted in the Swedish Baltic Sea (Jansson \& Wulff, 1977; Jansson et al., 1982). Similar studies of community metabolism of intertidal areas of the American Atlantic coast reveal the different characteristics of these areas compared to the Wadden Sea of the North Sea. One of the first measurements of community metabolism was conducted at the American Pacific coast (Pamatmat, 1968). Energy flow, carbon and nutrient cycles have been studied in various marine ecosystems (Odum, 1961; Odum \& Smalley, 1959; Odum \& Heald, 1972, 1975; Nixon et al., 1976, 1980; Pilson et al., 1979; Pomeroy et al., 1983).

Questions about energy flow and community metabolism in the Wadden Sea have been raised by de Wilde (1980) and Kuipers et al. (1981). These authors focussed their attention on comparing the significance of macrofauna with that of microbenthos (bacteria, microfauna, meiofauna). They postulated the dominance of microbenthos in processes of metabolic turnover. Even the high productivity of microbenthos was proposed to be a result of a high input of detritus. Thus, the Wadden Sea would depend to a high degree on the North Sea (De Jonge \& Postma, 1974). 
The present study is concerned with the primary and secondary production of three communities typical for the Wadden Sea of the North Sea coast. Community metabolism was measured in 1980, and energy flow is calculated. This study is the first attempt to quantify energy flow and the relation of primary production to secondary production in benthic communities of the northern Wadden Sea. The following question arises: Which trophic groups of macrofauna species are important to production, community metabolism and energy flow? The pathway of energy contained in food leading from primary to secondary producers should be clarified.

Estimates are based on measurements of community structure, primary and secondary production, respiration of single species as well as on the total oxygen consumption of the communities (bell jar experiments).

\section{AREA, MATERIAL AND METHODS}

The study area

Figure 1 shows the location of the "Königshafen", situated on the island of Sylt in the northern Wadden Sea (North Sea). The area of investigation is especially suitable because of little domestic, and no direct industrial sewage influence, also by the occurrence of the typical dominant intertidal benthic communities of the Wadden Sea within a small, well defined area. The species composition of the microflora communities is similar to that found in other areas of the Wadden Sea (Brockmann, 1950; Colijn \& Koeman, 1975; Colijn \& Dijkema, 1981). The structure of the macrofauna

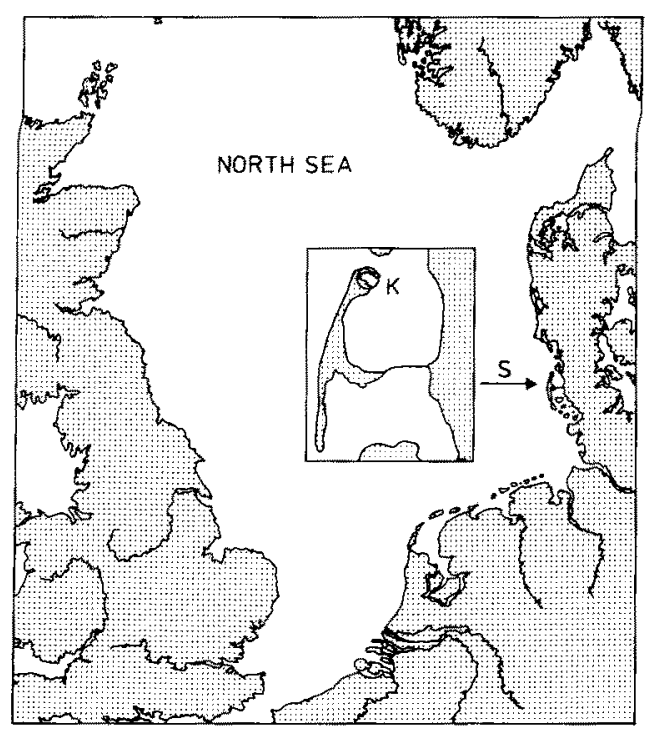

Fig. 1. The "Königshafen" area $(K)$ situated at the northern part of the island of Sylt (S) in the northern Wadden Sea (North Sea) 


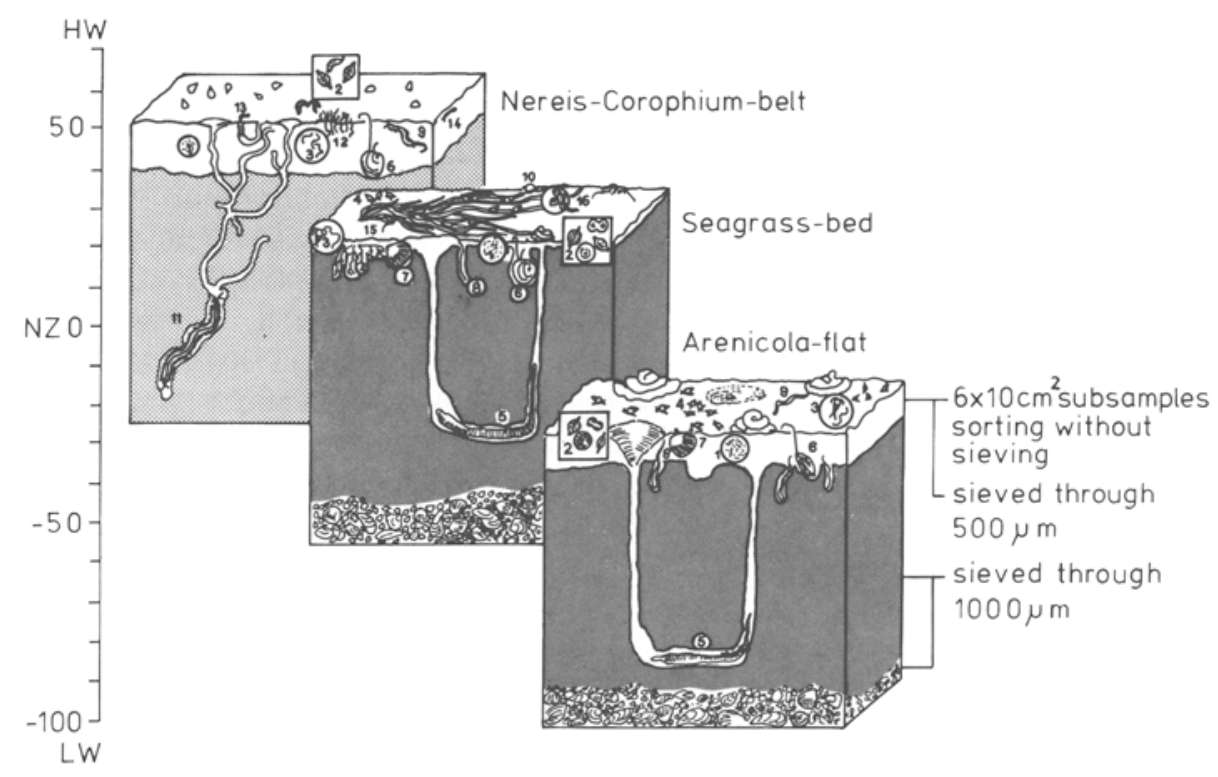

Fig. 2. Diagram of the important components of the communities Arenicola-flat, seagrass-bed, Nereis-Corophium-belt. The surfaces of the sediment cores mark the positions in $\mathrm{cm}$ in relation to midwater level (NZ). 1: bacteria, 2: microphytobenthos, 3: micro- and meiofauna, 4: Hydrobia ulvae, 5: Arenicola marina, 6: Macoma balthica, 7: Cerastoderma edule, 8: Scoloplos armiger, 9: Eteone longa, 10: Littorina saxatilis, 11: Nereis diversicolor, 12: Tubificidae, 13: Corophium volutator, 14: larvae of diptera, 15: Zostera noltii, 16: epiphytic diatoms

communities shows a pattern which is essentially the same for sandflat areas of the entire Wadden Sea (Linke, 1939; Beukema, 1976). The "Königshafen" is roughly $4 \mathrm{~km}$ long and $1 \mathrm{~km}$ wide. The tidal flats of the bight are drained through a central tidal channel. To the west and north, the bay is bordered by dunes separating the area from the open sea. To the south, marshy areas border the bay; at low tide $88 \%$ of the total "Königshafen" area are exposed. 55 \% of the "Königshafen" area are inundated for less than $6 \mathrm{~h}$. The tidal range has increased from $1.70 \mathrm{~m}$ to $1.80 \mathrm{~m}$ during the last few years.

The sediments of the tidal flats consist mainly of coarse sand; only in the western part of the bay and between mussel beds are there larger areas of muddy sediments. Structures of macrofauna communities of the "Königshafen" have been investigated since 1937 (Wohlenberg, 1937). Wohlenberg defined the different types of macrofauna communities in the "Königshafen". Reise (1978) described the communities again, showing a similar macrofauna distribution. In this study the Arenicola marina (old)Scoloplos community (Wohlenberg, 1937) includes the two sand flat communities. Areas of the sand flat communities covered by seagrass, mainly Zostera noltii Hornem. and little Zostera marina L. are called seagrass-beds in this study, and areas without seagrass are defined as Arenicola-flats. The sand flats just below the high water mark are defined as the Nereis-Corophium-belt. This area shows no settlement of A. marina. During the investigation Corophium volutator was scarce, but it has been very abundant in other 
years (Reise, 1978). The experimental sites are situated at different levels with different inundation times (Fig. 2). The Arenicola-flat extends from $0.75 \mathrm{~m}$ below the midwater level to $0.10 \mathrm{~m}$ above midwater level. The experimental site in this community is situated at a level of $0.30 \mathrm{~m}$ below midwater level. The Arenicola-flat is inundated for $6 \mathrm{~h}$ during one tide. The seagrass-bed covers the area between $0.10 \mathrm{~m}$ above midwater level and $0.40 \mathrm{~m}$ above midwater level. The experimental site is located $0.20 \mathrm{~m}$ above midwater level. This site is inundated for $4 \mathrm{~h}$ during one tide. Between $0.50 \mathrm{~m}$ above midwater level and the high water mark $(0.70 \mathrm{~m}$ above midwater level) the NereisCorophium-belt forms a narrow belt. This site is inundated for only two hours.

\section{Community metabolism}

The methods of field and laboratory measurements employed in this study are explained in a diagram (Fig. 3). Field measurements of community production and community respiration were carried out every month using closed chambers (bell jars) during submersion time. Measurements of community metabolism were not possible when the flats were covered with ice or on days with high wind (above Beaufort 7 ). These bell jar experiments were designed to measure primary production and total respiration simultaneously. Light bell jars were utilized to measure the primary production of the community. The total oxygen consumption was measured in dark bell jars. Small bell jars extend $13 \mathrm{~cm}$ and larger bell jars extend down to $30 \mathrm{~cm}$ deep into the sediment. $\mathrm{O}_{2}$ content in the bell jars was determined with the Winkler-technique every hour. The biological oxygen consumption was calculated as the difference between total

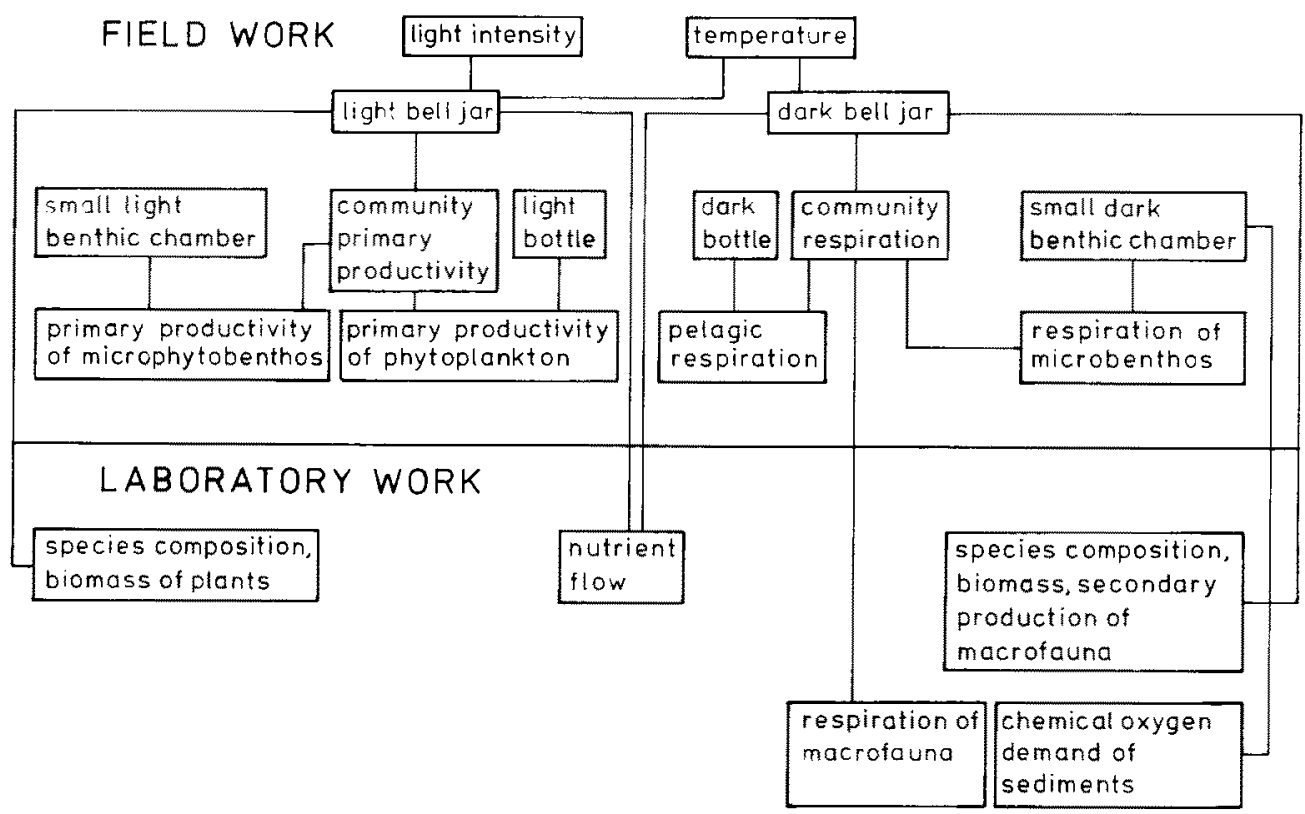

Fig. 3. Diagram of field and laboratory measurements 
oxygen consumption and chemical oxygen demand. The chemical oxygen demand was measured in small chambers containing sediments, which were poisoned with formaldehyde. At the beginning and the end of each field experiment run, nutrient samples $\left(\mathrm{NO}_{3}^{-}, \mathrm{NO}_{2}^{-}, \mathrm{NH}_{4}^{+}, \mathrm{Si}(\mathrm{OH})_{4}\right)$ were taken from inside and outside the bell jar. Results of nutrient analysis are presented in Asmus (1984).

\section{Primary and secondary production}

Every fortnight, phytoplankton production was measured with two light and one dark bottle $(300 \mathrm{ml})$ incubated in situ from $9 \mathrm{a} . \mathrm{m}$. to $3 \mathrm{p} . \mathrm{m}$. when high tide was at noon. Microphytobenthic primary production was measured with two light and one dark plexiglas chamber. Each chamber contained a macrofauna-free sediment layer of $0.3 \mathrm{~cm}$ thickness. Oxygen changes in the dark chambers represent the respiration of bacteria, microfauna, microflora, and chemical $\mathrm{O}_{2}$ demand. The chambers were filled with filtrated, oxygen saturated sea water and incubated in situ. Further measurements were carried out in the laboratory. For laboratory measurements of macrofauna respiration, open flow-through measuring devices were available. Recordings were carried out over $6 \mathrm{~h}$, the approximate time of submersion, and at in situ temperatures. Phytoplankton samples were taken for cell counts with an inverted microscope. Samples of microphytobenthos (core sampler: $0.64 \mathrm{~cm}^{2} \times 0.3 \mathrm{~cm}$ ) were taken during the field measurements. Diatom frustules from three samples were cleaned and embedded in Hyrax mounting medium. A fourth sample was preserved with formaldehyde to count those species destroyed by the cleaning procedure. Calculations of phytoplankton and microphytobenthos biomass expressed in carbon units were based on plasma volume following the recommendations of Edler (1979).

The macrofauna of the cores, included in the bell jar, was sorted, and biomass was determined. Sorted material was dried at $75-100^{\circ} \mathrm{C}$ for three days. Ash weight was determined after combustion in a furnace at $600^{\circ} \mathrm{C}$ for $2 \mathrm{~h}$. All data of weight and biomass are given in ash free dry weight. For production measurements, the individuals of dominant species were separated into year and weight classes. The monthly production per $\mathrm{m}^{-2}$ was estimated from changes in mean individual weight and mean numerical density of a weight class for each month using the following equation (after Winberg, 1971):

$$
\mathrm{P}=\left(\overline{\mathrm{W}}_{2}-\overline{\mathrm{W}}_{1}\right) \times 1 / 2\left(\overline{\mathrm{n}}_{1}+\overline{\mathrm{n}}_{2}\right)
$$

$P$ is monthly production, $\bar{W}_{1}$ and $\bar{W}_{2}$ are mean individual weights at time 1 and 2 , and $\bar{n}_{1}$ and $\bar{n}_{2}$ are the mean numerical densities at time 1 and 2 .

\section{RESULTS}

\section{Seasonal changes of plant and animal biomass}

In the flats investigated, the living organic substance at the sediment surface is dominated by the biomass of macrofauna. Biomass of microphytobenthos is small compared to this (Fig. 4). In the Arenicola-flat, benthic diatoms are the basis for primary production throughout the year. Maximum biomass of benthic diatoms is already reached at the end of February. Phytoplankton contributes to the biomass of plants 

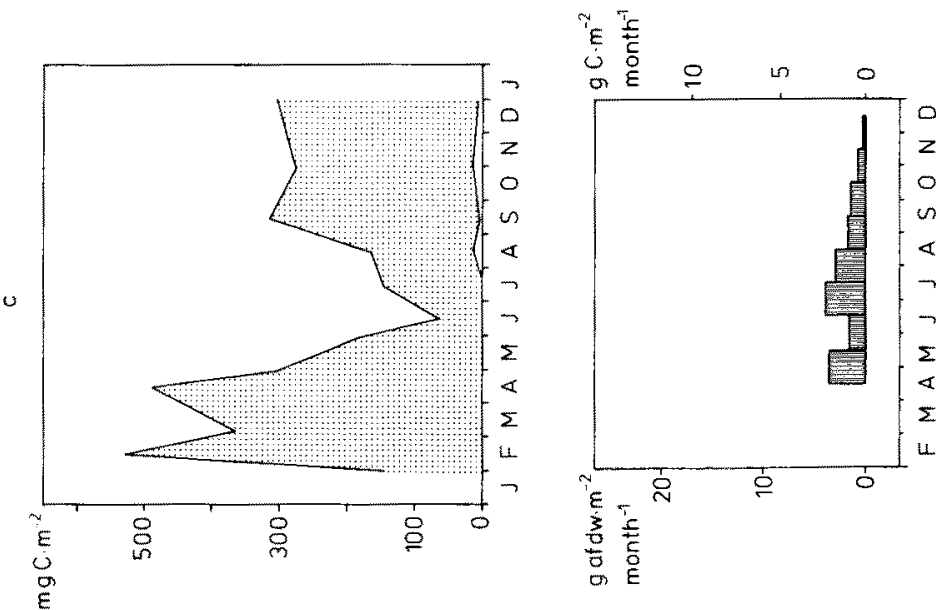

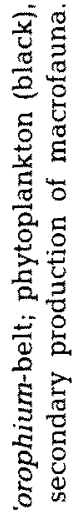

NE

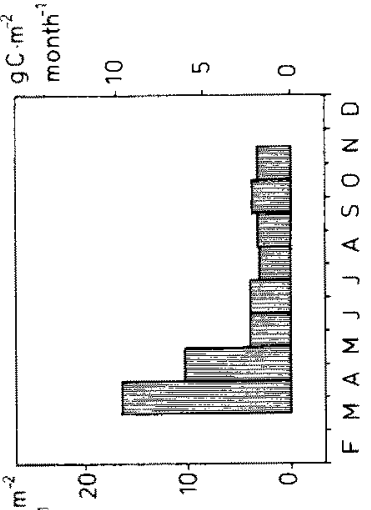

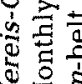

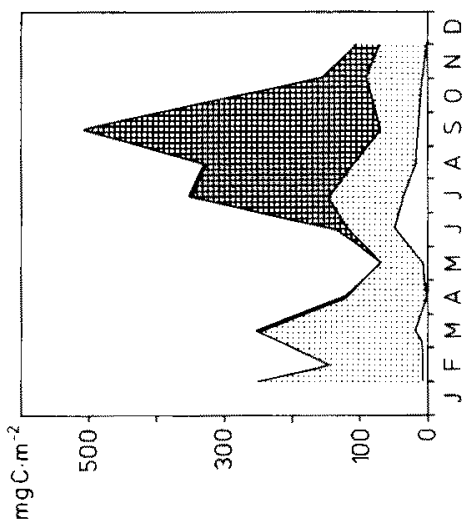

兘

$\ddot{0}$

ซु

$\$ 0$

客

氜

in

$\because 5$

菏

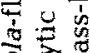

运哥

촌

$\ddot{0}$

灵

훙
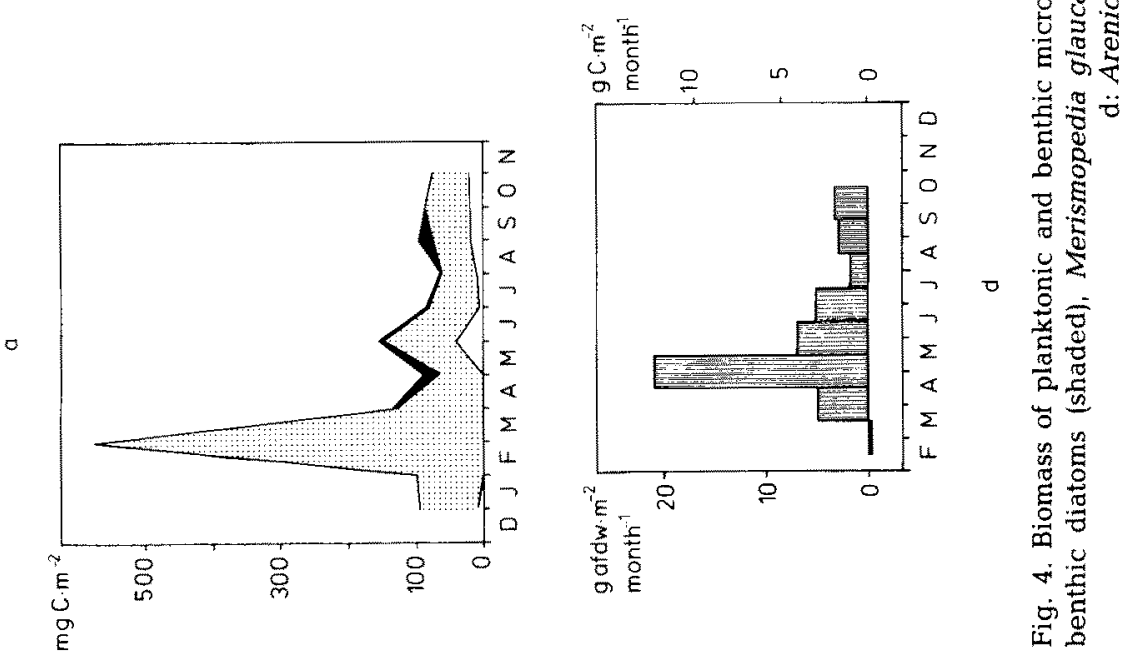

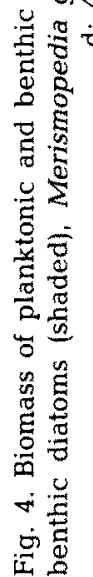


during spring and late summer blooms (Asmus, 1982). The biomass of macrofauna amounts to an annual average of $27.55 \mathrm{~g}$ afdw m$^{-2}$ (Table 1). The greater part of biomass is contributed by Hydrobia ulvae and Arenicola marina. The structure of biomass and species composition of the community at the Arenicola-flat has been described earlier (Asmus, H., 1982; Asmus, R., 1982). The synchrony of seasonal development of plant biomass and monthly secondary production attracts attention (Fig. 4a-f).

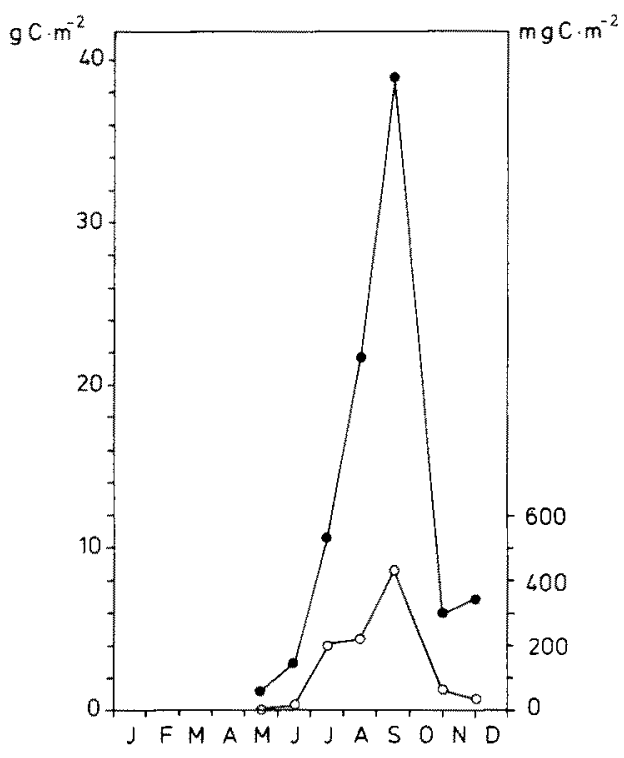

Fig. 5. Biomass of blades of Zostera noltii ( $\bullet$ scale on the left) and epiphytes ( 0 ; scale on the right)

In the seagrass-bed, the small seagrass Zostera noltii and its epiphytes (Fig. 5) are the most important primary producers in addition to microphytobenthos and phytoplankton. Zostera noltii grows from May until November. In the middle of September, seagrass forms the most dense cover, which soon after is grazed on by brent geese and wigeons. In July, the highest number of epiphytic diatoms per unit seagrass is reached, while highest total number per square meter is reached in September due to highest substrate biomass. In late winter, benthic diatoms form maximum biomass in the seagrass-bed as in the Arenicola-flat. The maximum biomass in the seagrass-bed is half as high as the maximum in the Arenicola-flat. In summer, the biomass of benthic diatoms in the seagrass-bed is lower than that of epiphytic diatoms. Blue green algae and phytoplankton constitute only a small part of the total plant biomass.

Macrofauna biomass amounts to $30 \mathrm{~g}_{\text {afdw }} \mathrm{m}^{-2}$ annual average. The dominant part is formed by $H$. ulvae and $A$. marina (Table 1 ).

In the Nereis-Corophium-belt the biomass of plants is dominated by benthic diatoms. As in the other communities, highest values of biomass are reached in late winter. Following a decrease from April to June, the biomass of benthic diatoms increases again and stays at this level until December, in contrast to that in other areas. This higher stock of benthic diatoms probably can develop as a result of lower density of 
macrofauna. Biomass of macrofauna is only half the annual mean of the other two communities; thus total feeding activity is reduced during the warm season. The most frequently encountered macrofauna species are $H$. ulvae and Nereis diversicolor.

Table 1. Annual mean biomass and constancy of species of macrofauna in the area of study. The constancy of a species corresponds to the number of samples in which this species is present as percentage of the total number of samples. (Total number of samples in the Arenicola-flat: 18, seagrass-bed: 18, Nereis-Corophium-belt: 16)

\begin{tabular}{|c|c|c|c|}
\hline \multirow[t]{2}{*}{ Species } & $\begin{array}{c}\text { Nereis- } \\
\text { Corophium-belt }\end{array}$ & $\begin{array}{l}\text { Seagrass- } \\
\text { bed }\end{array}$ & $\begin{array}{l}\text { Arenicola- } \\
\text { flat }\end{array}$ \\
\hline & \multicolumn{3}{|c|}{ biomass $\left(\mathrm{g}\right.$ afdw $\left.\mathrm{m}^{-2} \mathrm{a}^{-1}\right)$ (constancy \%) } \\
\hline \multicolumn{4}{|l|}{ Gastropoda } \\
\hline Hydrobia ulvae (Pennant) & $12.83(100)$ & $25.21(100)$ & $19.47(100)$ \\
\hline Littorina saxatilis (Olivi) & $0.04(13)$ & $0.75(78)$ & \\
\hline L. littorea L. & $0.01(6)$ & $0.12(17)$ & $0.04(17)$ \\
\hline L. obtusata L. & & $0.01(6)$ & \\
\hline Retusa obtusa (Montagu) & & $0.01(6)$ & \\
\hline \multicolumn{4}{|l|}{ Bivalvia } \\
\hline Cerastoderma edule L. & & $0.27(56)$ & $0.55(83)$ \\
\hline Macoma balthica L. & $0.89(88)$ & $0.74(100)$ & $1.08(100)$ \\
\hline Mya arenaria $\mathrm{L}$. & $0.01(13)$ & $0.45(28)$ & $0.03(50)$ \\
\hline Mytilus edulis L. & & $0.01(6)$ & \\
\hline \multicolumn{4}{|l|}{ Nemertini } \\
\hline Amphiporus lactifloreus (Johnston) & & $0.01(6)$ & \\
\hline Lineus viridis (Fabr.) Johnston & & $0.02(17)$ & $0.01(11)$ \\
\hline \multicolumn{4}{|l|}{ Polychaeta } \\
\hline Arenicola marina $\mathrm{L}$ & & $1.72(56)$ & $5.30(72)$ \\
\hline Anaitides mucosa (Oersted) & $0.01(13)$ & $0.22(89)$ & $0.12(78)$ \\
\hline Capitella capitata (Fabr.) & $0.01(19)$ & $0.08(83)$ & $0.03(50)$ \\
\hline Eteone longa (Fabr.) & $0.11(81)$ & $0.03(89)$ & $0.45(67)$ \\
\hline Harmothoe sarsi (Klingenberg) & & & $0.01(6)$ \\
\hline Heteromastus filiformis (Clap.) & & & $0.01(6)$ \\
\hline Nereis diversicolor (O. F. Müller) & $1.49(94)$ & & $0.01(6)$ \\
\hline Nephthys hombergi Savigny & & & $0.02(11)$ \\
\hline Pygospio elegans Claparede & $0.02(75)$ & $0.01(17)$ & \\
\hline Scoloplos armiger (O. F. Müller) & & $0.35(94)$ & $0.24(94)$ \\
\hline \multicolumn{4}{|l|}{ Oligochaeta } \\
\hline Tubifex spec. & $0.94(100)$ & $0.06(94)$ & $0.01(33)$ \\
\hline Edukemius benedeni Udekem & $0.01(25)$ & $0.12(100)$ & $0.17(100)$ \\
\hline \multicolumn{4}{|l|}{ Crustacea } \\
\hline Bathyporeia sarsi (Sars) & & $0.01(6)$ & \\
\hline Idothea balthica (Pallas) & & $0.01(6)$ & \\
\hline Jaera albifrons Leach & & $0.01(6)$ & \\
\hline Carcinus maenas $\mathrm{L}$. & & $0.01(6)$ & $0.02(6)$ \\
\hline Corophium volutator (Pallas) & $0.08(38)$ & & \\
\hline Crangon crangon $\mathrm{L}$. & & $0.01(6)$ & $0.02(6)$ \\
\hline \multicolumn{4}{|l|}{ In secta } \\
\hline larvae of diptera & $0.02(44)$ & & \\
\hline
\end{tabular}




\section{Monthly primary productivity}

Values of primary productivity of the Arenicola-flat have already been described (Asmus, R., 1982). The course of monthly primary productivity is shown in Figure $6 a+b$. Primary productivity is highest in the seagrass-bed due to the productivity of Zostera noltii and its epiphytes, which only here adds to the productivity of microphytobenthos and phytoplankton. In the seagrass-bed, primary productivity of microphytobenthos is a little lower than in the Arenicola-flat (Fig. 6b). Maximum primary productivity starts
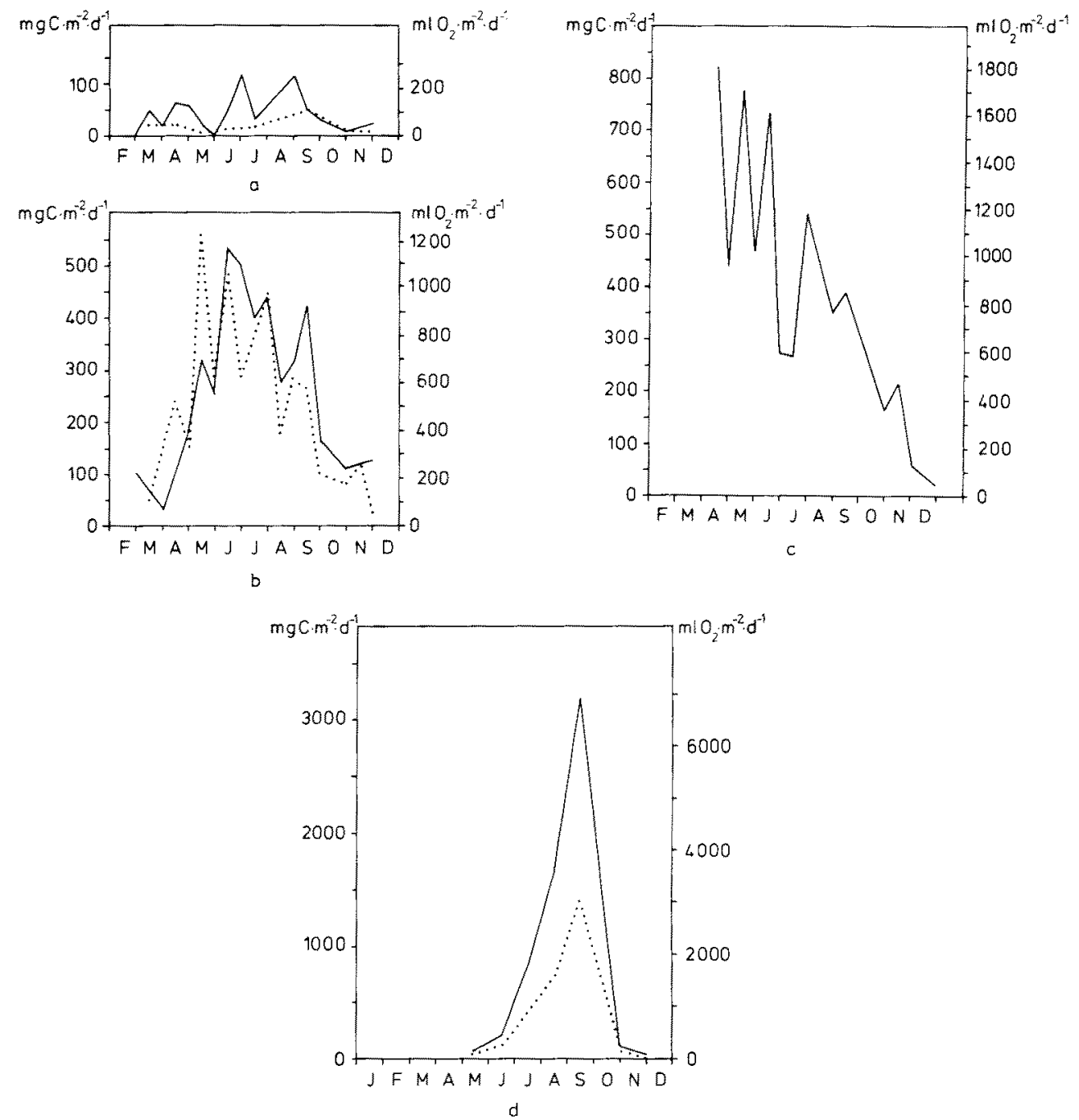

Fig. 6. Gross primary productivity a: of phytoplankton (Arenicola-flat: straight line, seagrass-bed: dotted line); b: of microphytobenthos (Arenicola-flat: straight line, seagrass-bed: dotted line); $c$; of microphytobenthos in the Nereis-Corophium-belt; d: gross and net (dotted line) primary productivity of Zostera noltii with epiphytes 
Table 2. Correlation between gross primary productivity and temperature or light intensity

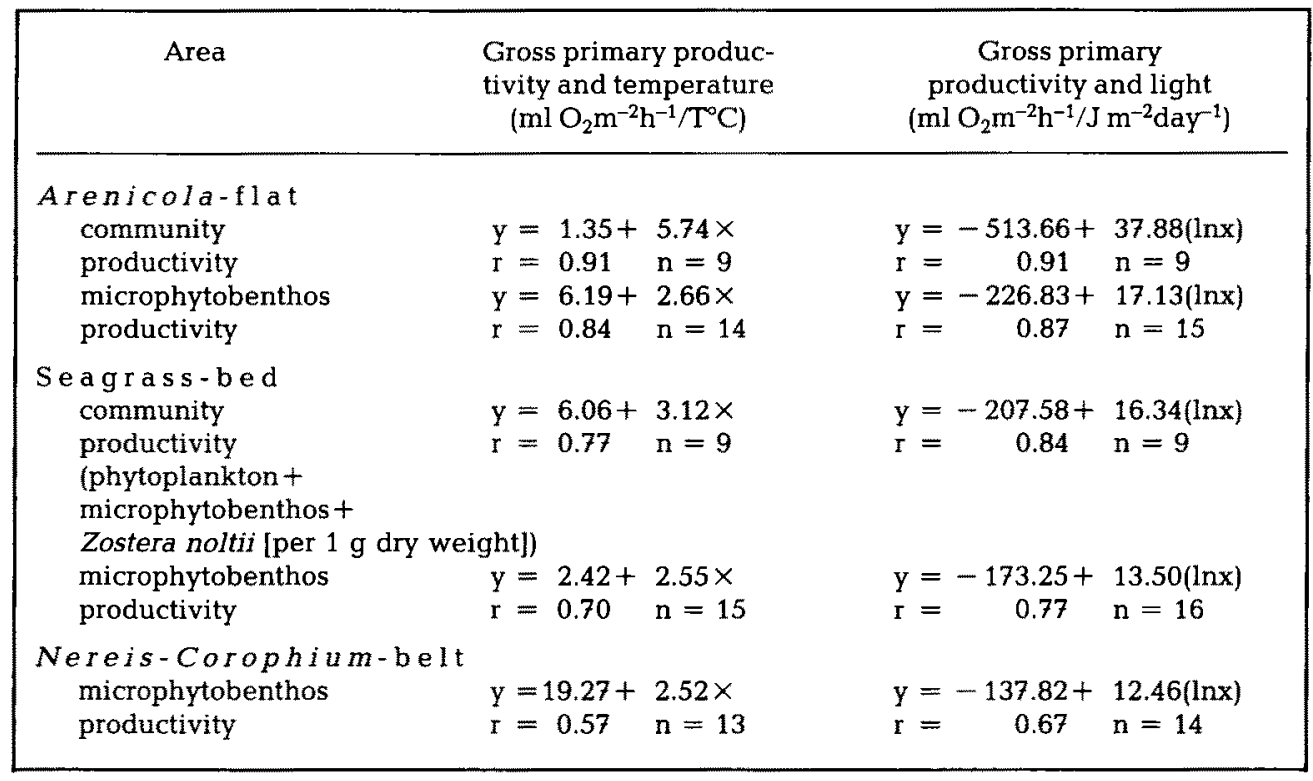

earlier in the seagrass-bed than in the Arenicola-flat. Additional differences are lower values of primary productivity in the seagrass-bed in June and September. Primary productivity of phytoplankton is lower than on the Arenicola-flat due to the shorter inundation period and lower water column (Fig. 6a). The activity of benthic diatoms determines the primary productivity in the Nereis-Corophium-belt (Fig. 6c). Primary productivity of microphytobenthos is higher than in the other two communities but it fluctuates strongly, especially in spring and summer. Primary productivity decreases from August to December. Increasing biomass of microphytobenthos is related to rising primary productivity. In contrast to this, the stock of biomass of microphytobenthos does not increase in the Arenicola-flat and in the seagrass-bed despite increasing primary productivity.

Here, high primary productivity is measured in summer when biomass of microphytobenthos is low. Primary productivity measured in bell jars and small benthic chambers (microphytobenthos) is strongly correlated with temperature and light intensity in all three communities (Table 2).

\section{Monthly secondary production}

In the Arenicola-flat, total production of macrofauna amounts to $50 \mathrm{~g}$ afdw m$^{-2} \mathrm{a}^{-1}$. Macrofauna consists for the greatest part of Hydrobia ulvae, Arenicola marina, Macoma balthica and Scoloplos armiger (Asmus, 1982). The maximum total macrofauna production is reached in spring between April and May. Nearly half the annual production has been formed by May. Negative values of production appear in winter between the end of February and the end of March. In midsummer (July/August) production of macrofauna is low; it rises again towards autumn (Fig. 4d). 
In the seagrass-bed, macrofauna produces $48 \mathrm{~g}$ afdw $\mathrm{m}^{-2} \mathrm{a}^{-1}$. Biomass amounts to $30 \mathrm{~g}_{\text {afdw }} \mathrm{m}^{-2} \mathrm{a}^{-1}$ on average, from which follows a P/B-ratio of 1.60 . H. ulvae has the greatest share in production, followed by $A$. marina and Littorina saxatilis. Seasonal variation of these shares is small. The maximum total macrofauna production is built up between March and April (Fig. 4e). During this time, one third of the annual production is formed. In summer, production decreases slowly down to the minimum in June. In midsummer, production of biomass rises again. From August till October, production values of the seagrass-bed are similar to those in the Arenicola-flat.

In the Nereis-Corophium-belt, total secondary production amounts to $17 \mathrm{~g}$ afdw $\mathrm{m}^{-2} \mathrm{a}^{-1}$. Between May and June, maximum macrofauna production is reached, corresponding to a quarter of annual production (Fig. 4f). In spring (by June), half of the annual production has already been formed. Production decreases in summer until a minimum is reached in autumn and winter.

\section{Annual balance of primary productivity}

Table 3a shows the partitioning of community primary productivity. The primary productivity of microphytobenthos is highest in the shallow Nereis-Corophium-belt, followed by lower production values in the Arenicola-flat and in the seagrass-bed. Net production means gross production minus respiration of total microbenthos in this connection. Supposing that the epiphytic diatoms of the seagrass produce per unit biomass (carbon) as much as the benthic diatoms in the seagrass-bed, the epiphytic annual mean productivity is estimated at $39.87 \% \pm 16.37$ (standard deviation) of the gross productivity of Zostera noltii. While primary productivity of phytoplankton is significant in the Arenicola-flat, planktonic productivity is two thirds less in the seagrass-bed; this results from a lower water depth and a shorter inundation period.

Primary productivity of the community is highest in the seagrass-bed. In the Arenicola-flat and in the Nereis-Corophium-belt, gross community primary productivity values are similar, although microphytobenthos and phytoplankton contribute to the community production in the Arenicola-flat and only microphytobenthos is active in the Nereis-Corophium-belt. The P/R-ratio (quotient of gross primary productivity and total community respiration) is lowest in the Arenicola-flat and rises towards the seagrass-bed and the Nereis-Corophium-belt (Table 3c).

The difference between gross primary productivity and the total respiration can be calculated for the total area of the three communities. It reveals that the primary productivity of the large Arenicola-flat is most important (Table 3d).

\section{Annual balance of secondary production}

The annual production of macrofauna is similar in the Arenicola-flat and in the seagrass-bed (Table $3 \mathrm{~b}$ ). Only about one third of this production is contributed by the Nereis-Corophium-belt.

The main part of production falls on Hydrobia ulvae. In the seagrass-bed and the Nereis-Corophium-belt, production of $H$. ulvae constitutes great fractions of $85 \%$ and $80 \%$, while in the Arenicola-flat this percentage is lower (43\%). In the Arenicola-flat, the production of the lugworm Arenicola marina forms an important part of the annual 
Table $3 a$. Annual balance of primary productivity $\left(\mathrm{gC} \mathrm{m}^{-2} \mathrm{a}^{-1}\right)$

\begin{tabular}{lccc|}
\hline & Arenicola-flat & Seagrass-bed & Nereis-Corophium-belt \\
\hline Microphytobenthos & & & \\
Gross & 115 & 85 & 152 \\
Net & 99 & 67 & 120 \\
Phytoplankton & & & - \\
Gross & 32 & 9 & - \\
Net & 28 & 8 & - \\
Zostera noltij & & & - \\
With epiphytes & - & 378 & \\
Gross & - & 167 & \\
Net & - & & \\
\hline
\end{tabular}

Table $3 b$. Annual secondary production

\begin{tabular}{|lccc|}
\hline & Arenicola-flat & Seagrass-bed & Nereis-Corophium-belt \\
\hline $\mathrm{g} \mathrm{afdw} \mathrm{m}^{-2}$ & 50.21 & 48.22 & 17.48 \\
$\mathrm{gC} \mathrm{m}^{-2}$ & 29.54 & 28.36 & 10.28 \\
\hline
\end{tabular}

Table 3c. Annual balance of the three communities

\begin{tabular}{|c|c|c|c|}
\hline & Arenicola-flat & Seagrass-bed & Nereis-Corophium-belt \\
\hline $\begin{array}{l}\text { Gross primary } \\
\text { productivity }\end{array}$ & $\begin{aligned} & 321 \mathrm{lO}_{2} \mathrm{~m}^{-2} \mathrm{a}^{-1} \\
= & 148 \mathrm{gC}\end{aligned}$ & $\begin{aligned} & 1034 \mathrm{lO}_{2} \mathrm{~m}^{-2} \mathrm{a}^{-1} \\
= & 473 \mathrm{gC}\end{aligned}$ & $\begin{aligned} & 332 \mathrm{lO}_{2} \mathrm{~m}^{-2} \mathrm{a}^{-1} \\
= & 152 \mathrm{gC}\end{aligned}$ \\
\hline Total respiration & $179 \mathrm{lO}_{2} \mathrm{~m}^{-2} \mathrm{a}^{-1}$ & $540 \quad 1 \mathrm{O}_{2} \mathrm{~m}^{-2} \mathrm{a}^{-1}$ & $130 \mathrm{lO}_{2} \mathrm{~m}^{-2} \mathrm{a}^{-1}$ \\
\hline $\begin{array}{l}\text { Net primary } \\
\text { productivity }\end{array}$ & $\begin{aligned} & 142 \mathrm{lO}_{2} \mathrm{~m}^{-2} \mathrm{a}^{-1} \\
= & 65 \mathrm{gC}\end{aligned}$ & $\begin{aligned} & 494 \mathrm{lO}_{2} \mathrm{~m}^{-2} \mathrm{a}^{-1} \\
= & 226 \mathrm{gC}\end{aligned}$ & $\begin{aligned} & 202 l^{1 O_{2} m^{-2} \mathrm{a}^{-1}} \\
= & 92 \mathrm{gC}^{-1}\end{aligned}$ \\
\hline $\mathrm{P} / \mathrm{R}$ & 1.79 & 1.91 & 2.55 \\
\hline
\end{tabular}

Table 3d. Primary productivity of the total area of the communities

\begin{tabular}{|lccc|}
\hline Community & $\begin{array}{c}\text { Area } \\
\text { (ha) }\end{array}$ & $\begin{array}{c}\text { Gross primary } \\
\text { productivity } \\
\text { (to C) }\end{array}$ & $\begin{array}{c}\text { Net primary } \\
\text { productivity } \\
\text { considering total } \\
\text { respiration (to C) }\end{array}$ \\
\hline Arenicola-flat & 121.61 & 179 & 79 \\
Seagrass-bed & 20.02 & 95 & 45 \\
Nereis-Corophium-belt & 21.80 & 33 & 20 \\
\hline
\end{tabular}


production $(30 \%)$. Other species play a minor role in secondary production. In the Nereis-Corophium-belt, Nereis diversicolor has a percentage of $9 \%$ in annual production of the community.

As the grazer $H$. ulvae is dominant in the three communities, macrofauna gains the major part of its energy for production via the grazing food chain. As epiphytes additionally are present in the seagrass-bed, energy transfer through the grazing food chain is of greater importance in this community. In this community, $83 \%$ of energy used for production are obtained from the grazing food chain. In the Arenicola-flat and in the Nereis-Corophium-belt, the significance of species other than grazers is greater than in the seagrass-bed.

\section{Community respiration}

The estimates of community metabolism are based on measurements of total oxygen consumption and their annual variations combined with field measurements of biological sediment activity. The total oxygen consumption $\mathrm{S}_{\mathrm{T}}$ is the sum of all chemical and biological oxygen consuming processes which influence the sediment surface:

$$
\mathrm{S}_{\mathrm{T}}=\mathrm{S}_{\mathrm{B}}+\mathrm{S}_{\mathrm{C}}
$$

Oxygen consumption due to biological processes $S_{B}$ corresponds to the community respiration in the oxic part of the environment. In this study, $S_{B}$ was calculated after subtraction of chemical oxygen consumption $S_{C}$ from total oxygen consumption $S_{T} \cdot S_{C}$ was measured in formaldehyde poisoned sediments. In situ oxygen consumption of microbenthos $S_{\text {micro }}$ (including microfauna, microflora and bacteria) is the difference between oxygen demand of the sediment $S_{A}$ and chemical oxygen consumption of the sediment $S_{C}$. The difference between $S_{T}$ and $S_{A}$ is equal to in situ oxygen consumption of macrofauna. Respiration of single macrofauna species is determined with laboratory experiments.

\section{Total oxygen consumption}

In the Arenicola-flat as well as in the seagrass-bed, total oxygen consumption increases from low values in winter to a maximum in summer (Fig. 7). Maximum total oxygen consumption in the Arenicola-flat is already reached in July whereas in the seagrass-bed it rises until September. In contrast to that, in the Nereis-Corophium-belt total oxygen consumption rises in spring to a high level. Maximum oxygen consumption is highest in the seagrass-bed $\left(197 \mathrm{ml} \mathrm{O}_{2} \mathrm{~m}^{-2} \mathrm{~h}^{-1}\right)$, followed by the Nereis-Corophiumbelt $\left(136 \mathrm{ml} \mathrm{O}_{2} \mathrm{~m}^{-2} \mathrm{~h}^{-1}\right)$. In the Arenicola-flat maximum oxygen consumption is lower $\left(52 \mathrm{ml} \mathrm{O}_{2} \mathrm{~m}^{-2} \mathrm{~h}^{-1}\right)$. In the Arenicola-flat total oxygen consumption rises with increasing temperature. In the other communities the effects of temperature on total oxygen consumption are superimposed by biotic factors.

\section{Oxygen consumption of macrofauna-free sediments $\left(\mathrm{S}_{\mathrm{A}}\right)$}

High sediment activities could be measured especially in spring and early summer in the Nereis-Corophium-belt. $\mathrm{S}_{\mathrm{A}}$ was low in the Arenicola-flat and in the seagrass bed. In the Arenicola-flat, oxygen consumption of sediments varies from 1.22 to $7.07 \mathrm{ml} \mathrm{O}_{2}$ $\mathrm{m}^{-2} \mathrm{~h}^{-1}$. Only in July, when the temperature rises to about $20^{\circ} \mathrm{C}$, is high oxygen 

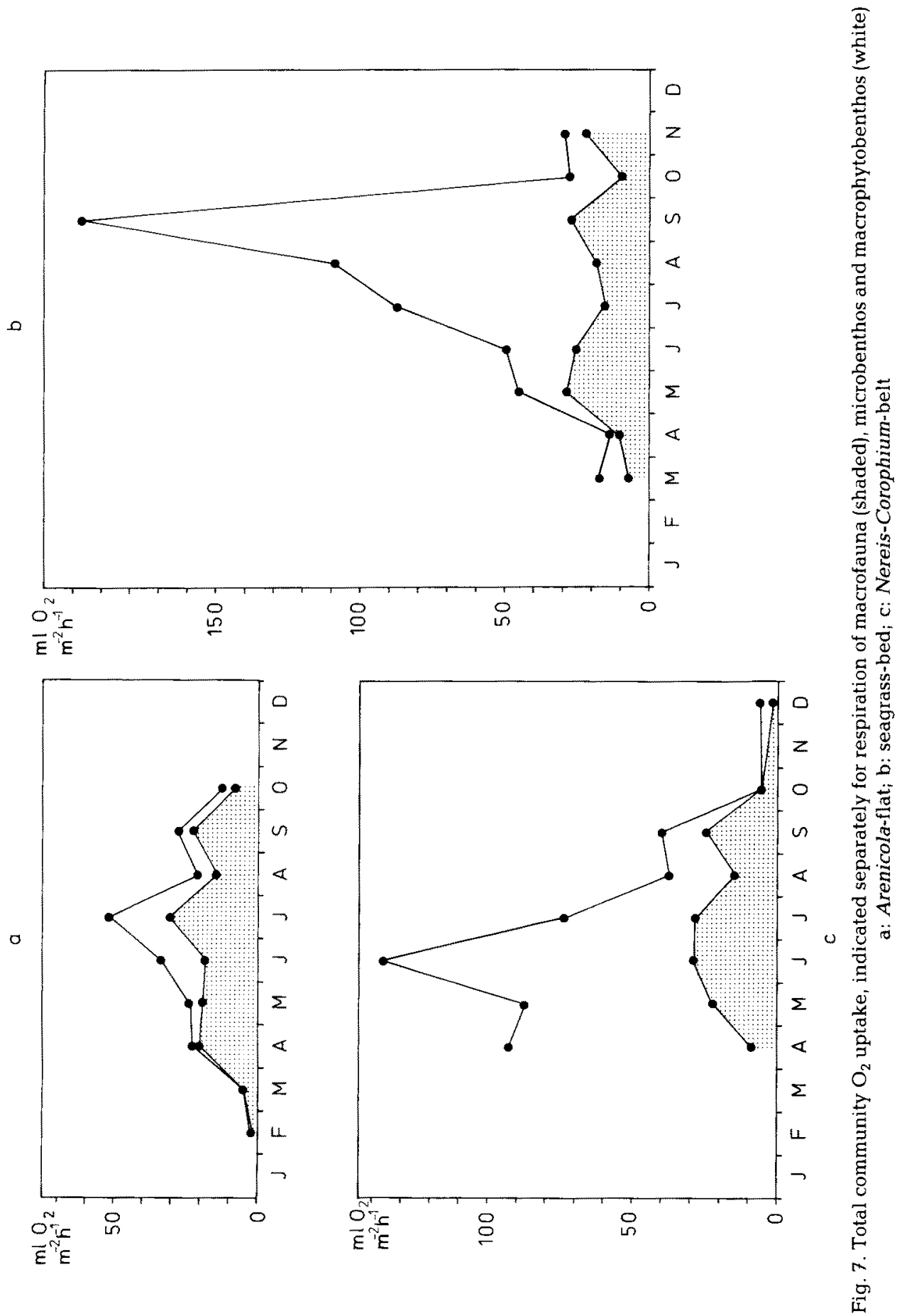
consumption of sediments of up to $25.04 \mathrm{ml} \mathrm{O} \mathrm{m}^{-2} \mathbf{h}^{-1}$ measured. Somewhat higher values of oxygen consumption are found in the seagrass-bed (up to $12.22 \mathrm{ml} \mathrm{O}_{2} \mathrm{~m}^{-2} \mathrm{~h}^{-1}$ ).

\section{Chemical oxygen consumption $\left(\mathrm{S}_{\mathrm{C}}\right)$}

The amount of oxygen consumed by chemical processes $\left(S_{C}\right)$ is much lower than that used by other processes. Average values are presented in Asmus, $H$. (1982). $S_{C}$ shows no significant differences between the experimental sites, but depends strongly on temperature. Because of the relatively simple structure of the investigated communities, some components with hardly measurable activities were negligible. Especially the respiration of plankton lies within the margin of error for the used bell jar technique $\left(1 \mathrm{ml} \mathrm{O}_{2}\right.$ $\left.\mathrm{m}^{-2} \mathrm{~h}^{-1}\right)$. Because of the lack of macrophytes in the Nereis-Corophium-belt and in the Arenicola-flat, the difference between $\mathrm{S}_{\mathrm{T}}$ and $\mathrm{S}_{\mathrm{A}}$ represents macrofauna respiration only.

\section{Estimates}

From the field measurements of $\mathrm{S}_{\mathrm{T}}, \mathrm{S}_{\mathrm{A}}, \mathrm{S}_{\mathrm{C}}$, oxygen consumption of macro- and microbenthos could be estimated by calculating the difference using the equations above.

Microbenthos respiration: $S_{\text {micro }}=S_{A}-S_{C}$. In spring, the NereisCorophium-belt is characterized by intense microbenthic respiration. This reflects the high activity of microphytobenthos which tends to form dense patches at that time. In the Arenicola-flat, microbenthic respiration ranges from 0.6 to $2.6 \mathrm{ml} \mathrm{O}_{2} \mathrm{~m}^{-2} \mathrm{~h}^{-1}$. Only in July do values up to $18 \mathrm{ml} \mathrm{O}_{2} \mathrm{~m}^{-2} \mathrm{~h}^{-1}$ appear. Microbenthic respiration in the seagrassbed is on average slightly higher $\left(0.1-7.6 \mathrm{ml} \mathrm{O}_{2} \mathrm{~m}^{-2} \mathrm{~h}^{-1}\right)$.

Respiration of macrobenthos: $S_{\text {macro }}=S_{T}-S_{A}$. In situ respiration of macrobenthos equals the difference between total oxygen consumption of the community and oxygen consumption of macrofauna-free sediments, if macrophytes are absent and respiration of water is of minor importance (Fig. 7). In the Arenicola-flat and in the Nereis-Corophium-belt macrofauna is the only component of macrobenthos, in the seagrass-bed macrophytobenthos is important. Respiration of macrobenthos constitutes the greatest share in oxygen consumption in all three communities. In the NereisCorophium-belt only, does respiration of microphytobenthos dominate in spring. Using laboratory experiments, shares of respiration are attributable to single macrofauna species. In the Arenicola-flat, $18.59 \mathrm{ml} \mathrm{O}_{2} \mathrm{~m}^{-2} \mathrm{~h}^{-1}$ are respired by macrofauna, $19.09 \mathrm{ml}$ $\mathrm{O}_{2} \mathrm{~m}^{-2} \mathrm{~h}^{-1}$ in the seagrass-bed and $16.58 \mathrm{ml} \mathrm{O}_{2} \mathrm{~m}^{-2} \mathrm{~h}^{-1}$ in the Nereis-Corophium-belt. Macrofauna species with high biomass predominate the amount of respiration. Consequently Hydrobia ulvae takes the greatest share in oxygen consumption.

\section{Annual balance of macrofauna respiration}

Although macrofauna respiration per hour is very similar throughout the year, macrofauna loses different quantities of energy through respiration (Arenicola-flat: $2237 \mathrm{~kJ}$, seagrass-bed: $3280 \mathrm{~kJ}$, Nereis-Corophium-belt: $1425 \mathrm{~kJ}$ ); the differences are a result of inundation time and thus of tide-induced variations of macrofauna activity. Laboratory measurements can determine shares of the trophic groups. Grazing species 
cause the highest values of respiration accomplished by detritus-feeding animals. Predators and suspension feeders are characterized by low overall oxygen consumption.

\section{Energy flow through the communities}

In the Arenicola-flat, plants utilize $7257 \mathrm{~kJ} \mathrm{~m}^{-2} \mathrm{a}^{-1}$ of solar energy for photosynthesis (gross primary productivity). Phytoplankton absorbs $18 \%$ of this energy and microphytobenthos absorbs $82 \%$. Because of the structural complexity of the plant community and the high biomass in the seagrass-bed, gross primary productivity is exceptionally high $\left(22914 \mathrm{~kJ} \mathrm{~m}^{-2} \mathrm{a}^{-1}\right)$. Seagrass utilizes $41 \%$ of this energy for gross primary productivity. Epiphytes produce further $38 \%$, and microphytobenthos has a share of $19 \%$ in total gross primary productivity in this community. The importance of phytoplankton is reduced drastically in the shallow area of the seagrass-bed $(1.65 \%)$. In the Nereis-Corophium-belt, only microphytobenthos is important $\left(7839 \mathrm{~kJ} \mathrm{~m}^{-2} \mathrm{a}^{-1}\right)$. Only a small part of the gross primary productivity is stored as plant biomass. A large amount is respired and a still greater part is transported to higher levels of the food web. It is difficult to distinguish between the respiration of plants and the total microbenthos in field experiments. Net primary productivity is given as a result of substraction of plant and microbial respiration from gross primary productivity. Total respiration of plants and microfauna amounts to $999 \mathrm{~kJ} \mathrm{~m}^{-2} \mathrm{a}^{-1}$ in the Arenicola-flat, $11900 \mathrm{~kJ} \mathrm{~m}^{-2} \mathrm{a}^{-1}$ in seagrass-bed and to $1660 \mathrm{~kJ} \mathrm{~m}^{-2} \mathrm{a}^{-1}$ in the Nereis-Corophium-belt. In the Arenicolaflat, net primary productivity is $6258 \mathrm{~kJ} \mathrm{~m}^{-2} \mathrm{a}^{-1}$. In the seagrass-bed, $11014 \mathrm{~kJ}$ and in the Nereis-Corophium-belt $6178 \mathrm{~kJ} \mathrm{~m}^{-2} \mathrm{a}^{-1}$ are transported as net primary productivity to higher trophic levels (Fig. 8).

Energy flow through the macrofauna in the Arenicola-flat amounts to $69 \mathrm{gC}$ $\mathrm{m}^{-2} \mathrm{a}^{-1}$. Between February and March a very low energy flow is measurable. In spring, energy flow rises due to increasing activity of the organisms. In May, energy flow starts to decrease and until July it remains at a level of $10 \mathrm{gC} \mathrm{m}^{-2}$ month ${ }^{-1}$. In midsummer and autumn, until the end of October, energy flow is reduced further. Two thirds of the total energy assimilated by macrofauna flow through Hydrobia ulvae. The part of energy flow used for production is $43 \%$, that of respiration is $57 \%$. These percentages fluctuate in the course of the year. In spring, production surpasses respiration, while in summer and autumn respiration constitutes the main part of energy flow. On the assumption that sources of food are used in proportion to their availability, $49 \mathrm{gC} \mathrm{m}^{-2} \mathrm{a}^{-1}$ are taken up by the grazing food chain and $20 \mathrm{gC} \mathrm{m}^{-2} \mathrm{a}^{-1}$ are taken up by the detritus food chain. Taking into consideration the total area of the Arenicola-flat (121.6 ha) $8.34 \times 10^{7} \mathrm{gC}$ or 83 to $\mathrm{C}^{-1}$ are assimilated by the community as a whole.

Energy flow through the macrofauna of the seagrass-bed amounts to $85 \mathrm{gC} \mathrm{m}^{-2} \mathrm{a}^{-1}$. As in the Arenicola-flat, energy flow is highest in spring. In summer, values are lower, but they rise again in late summer, $H$. ulvae contributes $89.7 \%$ to total assimilation. The share of production is $33 \%$ and the share of respiration is $67 \%$. In spring, the share of production in energy flow is high. $72 \mathrm{gC} \mathrm{m}^{-2} \mathrm{a}^{-1}$ are taken up by the grazing food chain and only $13 \mathrm{gC} \mathrm{m}^{-2} \mathrm{a}^{-1}$ by the detritus food chain. Energy flow per $\mathrm{m}^{2}$ is highest in the seagrass-bed, but as its area is relatively small $(20.02 \mathrm{ha})$, only $1.70 \times 10^{7} \mathrm{gC} \mathrm{a}^{-1}$ (17 to $\mathrm{C}^{-1}$ ) are taken up by the seagrass community.

In the Nereis-Corophium-belt, energy flow is $35 \mathrm{gC} \mathrm{m}^{-2} \mathrm{a}^{-1}$. In contrast to the other 
two areas maximum intensity of the energy flow is not reached before June/July. In winter, energy flow is hardly measurable. About two thirds of energy flow through macrofauna are attributable to $H$. ulvae in the Nereis-Corophium-belt. The share of production in total assimilation is $30 \%$, the share of respiration is $70 \%$. In the first half of the year the part going into production is higher. Never is the part used for production
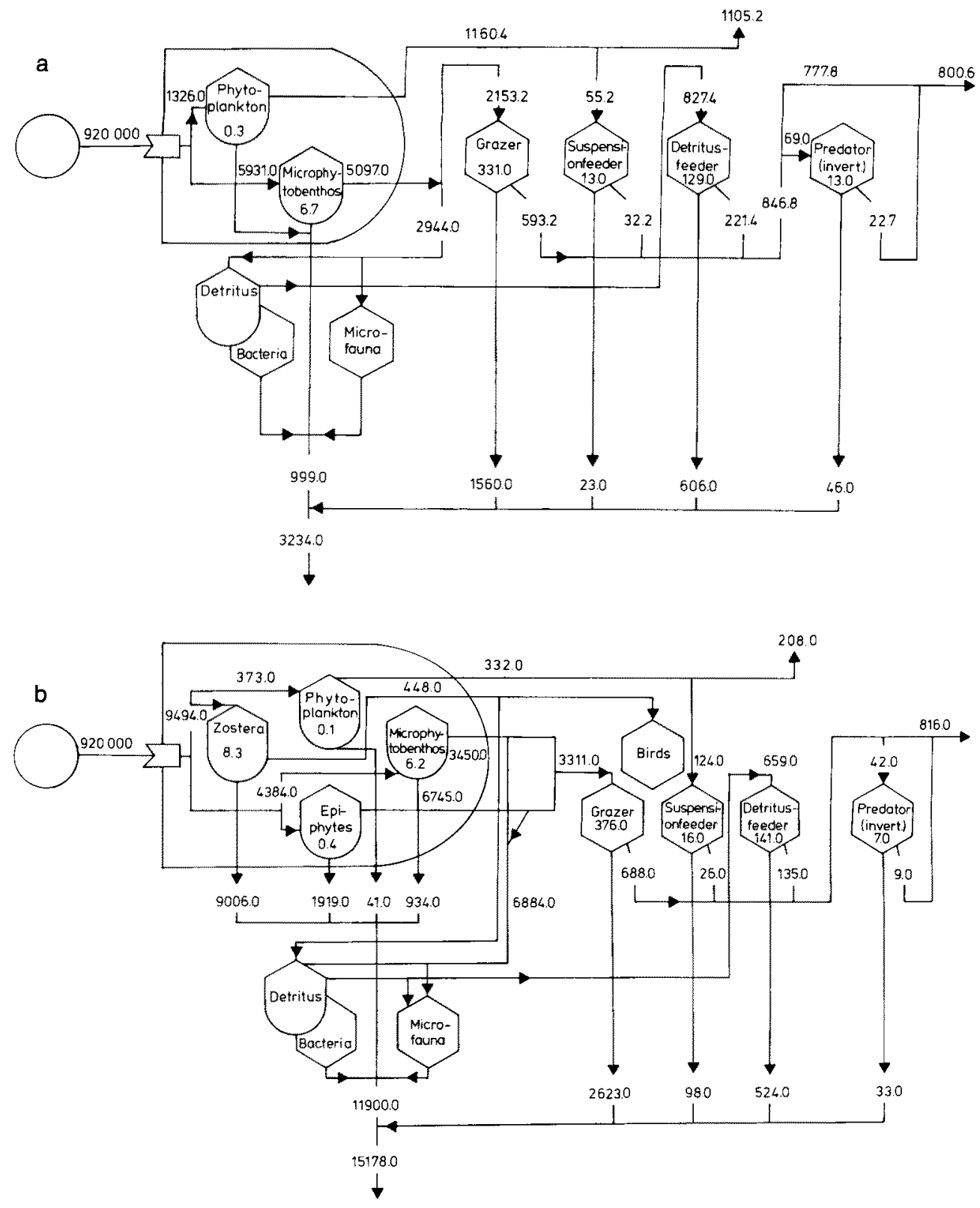


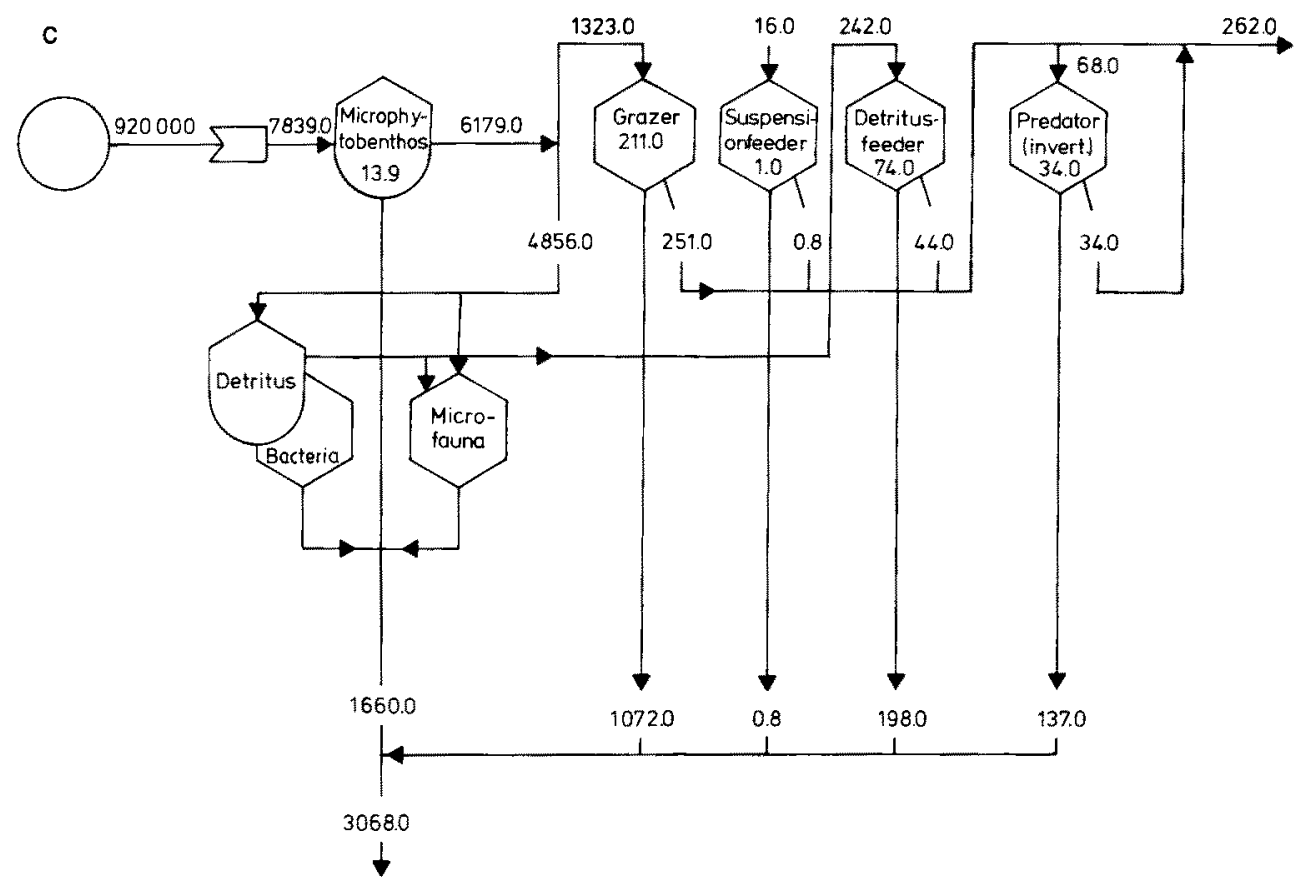

Fig. 8. Simplified models of energy flow of the three communities. a: Arenicola-flat; b: seagrassbed; c: Nereis-Corophium-belt. Figures with the symbols represent annual mean biomass $\left(\mathrm{kJ} \mathrm{m}^{-2}\right)$. Incoming solar radiation ( $\mathrm{kJ} \mathrm{m}^{-2} \mathrm{a}^{-1}, 400-700 \mathrm{~nm}$ wavelength) is shown on the left side. Figures by the arrows above the symbols indicate the energy flow; figures below the symbols in the right side reveal the production. Respiration of single components is specified in the lower row. The final value on the lower left hand side gives the total community respiration. All figures indicating energy flow, respiration and production are annual mean values $\left(\mathrm{kJ} \mathrm{m}^{-2} \mathrm{a}^{-1}\right)$. Tissue of macrofauna species shows different energy content. In this figure, $1 \mathrm{~g}$ afdw equals $17.83 \mathrm{~kJ}$ (gastropods); 17.82-20.77 kJ (bivalves); 17.70 (nemertines); 16.35 (Arenicola); 20.33 (other polychaetes); 16.10 (crustaceans); 22.29 (insect larvae) (cf. Jansson \& Wulff, 1977; Pollack, 1979)

higher than that used in respiration. $26 \mathrm{gC} \mathrm{m}^{-2} \mathrm{a}^{-1}$ are taken up by the grazing food chain and $5 \mathrm{gC} \mathrm{m}^{-2} \mathrm{a}^{-1}$ are taken up by the detritus food chain. In the NereisCorophium-belt, energy flow through macrofauna is less intense than in the other two communities. The total area of the Nereis-Corophium-belt in the "Königshafen" is $21.8 \mathrm{ha}$; thus, basing our calculation on these estimates, $0.76 \times 10^{7} \mathrm{gC}(7.56$ to $\mathrm{C})$ are taken up per year.

\section{DISCUSSION}

The three communities investigated differ distinctly with regard to the structure of their plant and animal components. In the biomass of the Arenicola-flat macrofauna, suspension feeders and detritus feeders constitute a greater part than in the seagrassbed. In the Nereis-Corophium-belt comparatively more invertebrate predators can be found. The three communities have in common the predominance of the small snail 
Hydrobia ulvae. The macrofauna biomass is in the same range in the Arenicola-flat and seagrass-bed, whereas in the Nereis-Corophium-belt the biomass amounts to one third only. Differences in inundation time mainly result in different periods of grazing.

\section{Primary productivity}

The primary productivity of microphytobenthos is as high as reported for other intertidal areas (Marshall et al., 1971; van Raalte et al., 1976; Cadée, 1980). The close correlations between primary productivity and light and temperature are in agreement with Leach (1970), Admiraal (1977), Colijn \& van Buurt (1975), Rasmussen et al. (1983), but were not found in in situ measurements by Colijn \& de Jonge (1984). A comparison of the $P / R$ ratios with those found in other areas reveal that the $P / R$ ratios of the "Konigshafen" area are high (Pamatmat, 1968; Jansson \& Wulff, 1977; Propp et al., 1980; Pomeroy $\&$ Wiegert, 1981). A P/R ratio above 1 is typical for a system in a "young" stage (Odum, 1980 ). When succession proceeds or pollution increases the $P / R$ ratio will decrease, as can be observed in the Ems-Dollard-estuary (van Es, 1982). In deeper water (20-25 m), on muddy sediments, respiration is higher than primary production, whereas on sand, photosynthesis may be appreciable at this depth (Propp et al., 1980). The primary productivity of Zostera noltii lies within the range of productivity measured in other areas (120-320 $\mathrm{g} \mathrm{C} \mathrm{m}^{-2} \mathrm{a}^{-1}$; Mann, 1982), with the exception of an investigation in the Lake Grevelingen (Lindeboom \& de Bree, 1982) where an extremely low value of $20 \mathrm{gC} \mathrm{m}^{-2}$ per growing season net productivity was found.

Compared with the scale of primary productivity in different areas of the oceans (Ryther, 1969), the primary productivity in the Arenicola-flat and in the NereisCorophium-belt is in the upper range of the productivity on the continental shelf. The primary productivity in the seagrass-bed is in the range of very high productive areas. The primary productivity of the whole sand flat is to be considered as high, but not as extremely high. The importance of the different groups of primary producers may vary distinctly even in other shallow waters. In the Wadden Sea, microphytobenthos is the most productive group, whereas in tropical lagoons phytoplankton and mangrove trees are found to be more important than microphytobenthos and seagrass (Day et al., 1982). In several shallow water areas of the Baltic, the main part of primary production is stored in the biomass of macroalgae and therefore it is not available to herbivore grazing.

\section{Secondary production}

The first estimate of secondary production of macrofauna was possible by using the Boysen-Jensen-method (Boysen-Jensen, 1919). Seasonal variations of total biomass of macrofauna were observed by Beukema $(1974,1981)$. Often secondary production of populations of single species is investigated, and the production of the whole community has to be calculated with the aid of data not measured simultaneously. In this study, secondary production is determined as the product of individual growth increments and mean population density. Because significant changes in biomass of populations do not occur during the year, it can be inferred that elimination of biomass is just compensated by secondary production. Secondary production in the "Königshafen" is comparable to that in other intertidal areas and estuaries $\left(13 \mathrm{~g}\right.$ afdw $\mathrm{m}^{-2} \mathrm{a}^{-1}$; Warwick \& Price, 1975 ; 
$120 \mathrm{~g} \mathrm{afdw} \mathrm{m}^{-2} \mathrm{a}^{-1}$ [maximum]; Wolff \& de Wolf, 1977). Up to now, estimates of secondary production of macrofauna amount to $30 \mathrm{~g} \mathrm{afdw} \mathrm{m}^{-2} \mathrm{a}^{-1}$ for the Dutch Wadden Sea, based on values of biomass determined after sieving with $1 \mathrm{~mm}$ mesh (Beukema, 1981). Production of organisms passing through a sieve of $1 \mathrm{~mm}$ mesh size is considered to be low (up to $10 \mathrm{~g}$ afdw $\mathrm{m}^{-2} \mathrm{a}^{-1}$; Beukema, 1981). Secondary production of larger macrofauna is mentioned to be $18 \mathrm{~g} \mathrm{C}$ (Beukema, 1981), thus $18 \%$ of primary production is used directly for secondary production of larger macrofauna.

If the production of Hydrobia ulvae $\left(12.6 \mathrm{~g} \mathrm{C} \mathrm{m}^{-2} \mathrm{a}^{-1}\right)$ were disregarded in this investigation, secondary production would amount to $17 \mathrm{~g} \mathrm{C} \mathrm{m}^{-2} \mathrm{a}^{-1}$ in the Arenicolaflat which is similar to sand flats of the Dutch Wadden Sea. Kuipers et al. (1981) have shown that food supply consisting of $100 \mathrm{~g} \mathrm{C} \mathrm{m}^{-2} \mathrm{a}^{-1}$ primary production and $250 \mathrm{~g}$ $\mathrm{C} \mathrm{m}^{-2} \mathrm{a}^{-1}$ detritus input (de Jonge \& Postma, 1974) is used up by secondary production (18 $\mathrm{g} \mathrm{C} \mathrm{m}^{-2} \mathrm{a}^{-1}$ ) to only a low degree. The small food web which includes microfauna and small macrofauna like $H$. ulvae fills this gap representing a link between primary and secondary producers. From meiofauna biomass which consists mainly of nematodes, Witte \& Zijlstra (1984) estimated a secondary production of meiofauna of $3.6 \mathrm{~g} \mathrm{C} \mathrm{m}^{-2} \mathrm{a}^{-1}$ at Balgzand. Together with a production of $12.6 \mathrm{~g} \mathrm{C} \mathrm{m}^{-2} \mathrm{a}^{-1}$ for small macrofauna in our investigation, it leads to a value of $16.2 \mathrm{~g} \mathrm{C} \mathrm{m}^{-2} \mathrm{a}^{-1}$ for secondary production of the small food web.

This value shows that the production of the small food web including microfauna and small macrofauna can amount to a similar order of magnitude as production of larger macrofauna.

\section{Community respiration}

In a community, total annual oxygen consumption of sediment surface is a realistic measure of that part of organic material respired in the sediment (Hargrave, 1972; Pamatmat, 1975). Community metabolism is underestimated by measurements of oxygen consumption in a community where anaerobic processes take place. Further difficulties in interpretating results of bell jar experiments arise through differences between the oxygen budget of disturbed and undisturbed sediments. The balance of erosion and sedimentation determines to what degree energy flow of the community can be calculated from oxygen demand (Pamatmat, 1975). Strong storms may reactivate material in sheltered shallow bays like the "Königshafen". Measurements which are only possible on days of quite calm weather give a realistic picture of the energy flow and aerobic community metabolism.

Annual oxygen demand amounts to $1801 \mathrm{~m}^{-2} \mathrm{a}^{-1}$ (Arenicola-flat), $540 \mathrm{l} \mathrm{m}^{-2} \mathrm{a}^{-1}$ (seagrass-bed) and $1301 \mathrm{~m}^{-2} \mathrm{a}^{-1}$ (Nereis-Corophium-belt). Respective differences between the amounts of total oxygen consumption of the three communities are considerable. Respiration is highest in the seagrass-bed as a result of the predominant respiration of Zostera noltii. Respiration amounts to $64 \mathrm{ml} \mathrm{O}_{2} \mathrm{~m}^{-2} \mathrm{~h}^{-1}$ on average in the seagrass-bed. In the Arenicola-flat, community respiration is predominated by macrofauna. In the Nereis-Corophium-belt, the participation of macrofauna in respiration varies strongly $(9-68 \%)$; in the seagrass-bed only $20 \%$ of community respiration are contributed by macrofauna because of high seagrass respiration. Total amounts of macrofauna respiration at the three stations are very similar despite their different shares in community respiration. 
Partitioning of respiration of different shallow water communities revealed $45 \%$ macrofauna respiration on average (Zeitzschel \& Davies, 1978). In the Arenicola-flat the participation of macrofauna in respiration is quite high while in the other two areas it corresponds with data in literature (Banse et al., 1971; Pamatmat $\&$ Banse, 1969; Smith et al., 1972).

Sediments of the Arenicola-flat are characterized by large individuals of Arenicola marina. A high percentage of macrofauna respiration in total respiration can be due to the presence of large sized macrofauna individuals (Nichols, 1972). Pamatmat (1975) did not find this relationship and concluded an anaerobic metabolism of large individuals in in situ experiments, whereas rates of oxygen consumption were high in laboratory experiments at conditions of oxygen saturation. It is known that $A$. marina may shift to anaerobic metabolism (Schöttler, 1980). It is open to discussion whether oxygen deficiency occurs in the burrows of $A$. marina even when the water above is oversaturated $(150-200 \%)$ as in the "Königshafen" when the worm repeatedly pumps water through its burrow (Baumfalk, 1979). At low tide, mussels may have switched over to anaerobic metabolism.

Up to now there is no indication of anaerobic metabolism in the dominant species of the three communities, Hydrobia ulvae. In previous studies, macrofauna respiration may have been underestimated because the bell jars may have been too small or may have caused the burrows to clog with sediment by disturbing the surrounding area.

The results of bell jar experiments in areas free of macrophytobenthos show oxygen demand of 1-190 $\mathrm{ml} \mathrm{O}_{2} \mathrm{~m}^{-2} \mathrm{~h}^{-1}$ (Duff \& Teal, 1965; Pomeroy, 1959, 1960; Teal \& Kanwisher, 1961; Wieser \& Kanwisher, 1961). Most values range from $15-50 \mathrm{ml} \mathrm{O}$ $\mathrm{m}^{-2} \mathrm{~h}^{-1}$. Mean oxygen consumption of $23 \mathrm{ml} \mathrm{O}_{2} \mathrm{~m}^{-2} \mathrm{~h}^{-1}$ (Arenicola-flat) and $59 \mathrm{ml} \mathrm{O}$ $\mathrm{m}^{-2} \mathrm{~h}^{-1}$ (Nereis-Corophium-belt) are in agreement with this range. In the seagrass-bed, the value of community respiration is relatively low compared with other macrophytobenthos communities. But $Z$. noltii grows actively only from June to October. During this period, the mean value of respiration is $109 \mathrm{ml} \mathrm{O}_{2} \mathrm{~m}^{-2} \mathrm{~h}^{-1}$ and corresponds to values from other phytal regions (Jansson \& Wulff, 1977; Asmus et al., 1980). In the Dutch Wadden Sea, first measurements of community metabolism suggest that oxygen is mainly taken up by the small food web (bacteria, microfauna, small macrofauna), while maximum macrofauna respiration should only be $20-30 \%$ (Kuipers et al., 1981). Van Es (1982) points out the important role of bacteria in community metabolism. However, the methods of measurements are so different (e.g. at low tide) that the results do not seem to be comparable. Microbenthic algae often dominate respiration of microbenthos (Wieser \& Kanwisher, 1961; Pamatmat, 1968), while microfauna has a medium share of $10-30 \%$ (Wieser \& Kanwisher, 1961). In the area of investigation, respiration of microbenthos was high only at temperatures of about $20^{\circ} \mathrm{C}$, and probably caused by bacteria (Asmus, 1983). In winter, values of microbenthos respiration were generally low, higher values found occasionally were due to algal activity. The role of microfauna is only of minor importance for the oxygen budget although microfauna is very abundant in the area (see Reise, $1981 \mathrm{a}, \mathrm{b})$. Nematodes and copepods predominate in the microfauna. In July 1980, an average of 875000 nematodes and 240000 copepods per square meter lived in the upper $5 \mathrm{~cm}$ of sediment in the Arenicola-flat (Reise, pers. communication). Assuming that respiration of nematodes is $1.5 \mathrm{ml} \mathrm{O}_{2} \mathrm{~g}^{-1}$ wet weight and that respiration of harpacticoides is $1.0 \mathrm{ml} \mathrm{g}^{-1}$ wet weight (Jansson \& Wulff, 1977), total respiration of nematodes 
and copepods amounts to $0.43 \mathrm{ml} \mathrm{O}_{2} \mathrm{~m}^{-2} \mathrm{~h}^{-1}$ and $0.30 \mathrm{ml} \mathrm{m}^{-2} \mathrm{~h}^{-1}$ respectively. Respiration of microfauna might not be higher than $1 \mathrm{ml} \mathrm{O}_{2} \mathrm{~m}^{-2} \mathrm{~h}^{-1}$ in the warmest month of the year. It is certainly lower during the colder seasons. Values of this magnitude are negligible compared with the importance of other components even if one supposes higher abundance due to microfauna living in burrows of macrofauna (Reise, 1981a).

\section{Energy flow}

Solar radiation is the major energy source for the community investigated. Other sources of energy from outside seem to be of minor importance. Detritus input is assumed to be high in many other intertidal areas, which in most cases show high sedimentation rates during high tides. The sediments of the communities studied are characterized by coarse sands with a relatively low detritus content. Microscopical analysis shows that the detritus is produced by members of the community itself. This leads to the assumption that sedimentation of detritus material may be low in general. Only strong sediment reworking through storms causes an increase in detritus content and transport of the water for a short time. But these processes have not been quantified up to now. Energy from solar radiation is incorporated into plants. Primary production of microphytobenthos does not cause an increase in plant biomass. A storage of energy does not occur. Production is used to compensate biomass losses through feeding by heterotrophs. A high abundance of herbivorous macrofauna decreased biomass and production of benthic microalgae in other areas (Hargrave, 1970; Darley et al., 1981; Pace et al., 1979; Davis \& Lee, 1983; Hickman \& Round, 1970; Taasen \& Høisaeter, 1981; Branch \& Branch, 1980; Connor et al., 1982), whereas a lower density of macrofauna may stimulate the growth of microphytobenthos (Hargrave, 1970; Connor et al., 1982). In the NereisCorophium-belt, biomass losses of microphytobenthos caused by herbivores amount to only one third to one half the losses in other communities. Thus, a higher level of microphytobenthos biomass can be maintained.

Macrophytes and epiphytes grow only from May until November, and only from August to September does the macrophytic and epiphytic biomass exceed the biomass of the other compartments. In the other half of the year, no biomass of Zostera and epiphytes is developed; thus mean annual biomass of this compartment is relatively low. Zostera loses a significant part of the assimilated energy by its own respiration and a minor amount of energy remains for production of biomass. This production leads to an increase in biomass and forms an energy storage during the vegetation period. At the end of the vegetation period, most of the energy stored by Zostera plants is lost to herbivorous birds. In most of macrophytobenthos based systems the plant biomass is utilized for higher trophic levels only after degradation to detritus (Mann, 1982). After defoliation in autumn, waves and tidal currents wash the leaves of Zostera noltii onto the shore, where degradation processes take place, and only a part of seagrass production will enter the detritus pool of the seagrass bed. Interactions between primary and secondary producers are so intense that the question arises whether primary production per year is high enough to maintain the macrofauna community. In the three communities investigated, primary production is usually higher than secondary production.

In the Arenicola-flat, $68 \%$ of secondary production are utilized by the grazing food chain. This share is highest in the seagrass-bed $(83 \%)$, while in the Nereis-Corophium- 
belt it is $76 \%$. The total amount of primary production is reflected in the degree of utilization by the grazing food chain. Values of primary production and secondary production are shown in Table 4. Primary production of benthic diatoms is utilized in the Arenicola-flat and seagrass-bed with an efficiency of $20 \%$ more effectively than in the Nereis-Corophium-belt, where efficiency is only $7 \%$.

Epiphytes are used with an efficiency of only $7 \%$. This low efficiency is caused by the low biomass of consumers at the beginning of summer. Numbers of consumers increase during the next season.

Even secondary production is lower in summer than at the beginning of the year. Due to higher temperatures in summer, more energy has to be spent for respiration, thus epiphytic primary production is converted into macrofauna secondary production to a much lower extent. The efficiency of energy transfer from total primary production (without macrophytes) to total secondary production is $29 \%$ (Arenicola-flat), $14 \%$ (seagrass-bed) and $9 \%$ (Nereis-Corophium-belt). It shows that primary production of all three communities is sufficient to meet the food demand of the macrofauna communities. A further increase of production efficiency is impossible, because food supply is spent to a high degree for macrofauna respiration especially in summer.

Secondary production forms the main source of food for invertebrate and vertebrate predators on the tidal flat. In this investigation only small predators could be considered (Anaitides, Nereis, Lineus etc.) which are permanently present on the tidal flat. These predators use only a small part of the biomass built up by secondary producers. The main part of secondary production is consumed by larger predators visiting the tidal flat during high tide, or by predating birds during low tide. Secondary producers are strongly affected by predators (Reise, 1978), but the knowledge about the energy transfer from this trophic level to the tertiary producers is still insufficient. About $260-816 \mathrm{~kJ}$ $\mathrm{m}^{-2} \mathrm{a}^{-1}$ are available to tertiary producers according to the estimates of this study.

\section{Importance of grazing food chain}

Effects of grazers upon primary producers could be observed in the three communities studied. These interactions affect the stock and production of different trophic levels as well as the structure of trophic elements in the communities. The great importance of benthic diatoms as food source is reflected in the production and biomass of herbivorous macrofauna. Due to the dominance of Hydrobia ulvae in the three communities the main pathway of energy can be described as beginning with benthic diatoms leading chiefly to small grazing animals and to higher trophic levels.

The following arguments support the great importance of the grazing food chain: (1) Autochthonous primary productivity is sufficient to meet the food requirements of macrofauna. (2) Macrofauna of the communities investigated is dominated by species which feed on primary producers. The dominant $H$. ulvae prefers benthic diatoms as food (Fenchel \& Kofoed, 1976; Jensen \& Siegismund, 1980). (3) In spite of high primary productivity during summer, the biomass of benthic primary producers does not accumulate.

Hence, the community does not need an import of detritus from outside to maintain its high macrofauna biomass. There is no evidence that benthic microalgae are rejected as food in favour of detrital particles. 
Are these results representative for other years and other intertidal areas? During this investigation the climatic conditions were by no means unusual. Summer temperatures coincided with the long term average of this area, whereas the mean winter temperatures $1979 / 80$ were slightly lower than the long term average.

Benthic diatoms are known as important primary producers in most intertidal areas and they build up a rich food source for grazing animals, but their role for marine food webs has been underestimated in the past. Although sediments in Königshafen are relatively coarse grained, the macrofauna closely resembles those of other tidal areas in north western Europe (see Wohlenberg, 1937), and the species composition in the tidal zone has remained relatively stable over the last decades (Reise, 1982). From these areas and also from other tidal flats in the world, high abundances of grazers are well known (Macnae \& Kalk, 1962; Dörjes, 1978; Pace et al., 1979; Branch \& Branch, 1980; Race, 1982).

Consequently, it can be expected that the pattern of energy flow and the importance of grazing food chain of similar intertidal sand bottoms will be comparable to those in this study, and that the benthic grazing food chain has a greater importance than supposed till now.

Acknowledgements. The authors are indebted to the former director of the Biologische Anstalt Helgoland, Prof. Dr. O. Kinne, for the hospitality at the Littoral Station in List. Dr. K. Reise, Prof. Dr. H. Theede and Prof. Dr. B. Zeitzschel promoted this study with helpful advice. Thanks are due to Mrs. G. Kredel and Mrs. D. Barthel for kindly revising the English text, and also to the members of the Littoral Station. A grant was awarded by the Friedrich-Naumann-Stiftung and by the Deutsche Forschungsgemeinschaft.

\section{LITERATURE CITED}

Admiraal, $W$, , 1977. Influence of light and temperature on the growth rate of estuarine benthic diatoms in culture. - Mar. Biol. 39, 1-9.

Asmus, H., 1982. Field measurements on respiration and secondary production of a benthic community in the Northern Wadden Sea. - Neth. J. Sea Res. 16, 403-413.

Asmus, H., Theede, H., Neuhoff, H.-G. \& Schramm, W., 1980. The role of epibenthic macrofauna in the oxygen budget of Zostera communities from the Baltic Sea. - Ophelia (Suppl.) 1, 99-111.

Asmus, R., 1982. Field measurements on seasonal variation of the activity of primary producers on a sandy tidal flat in the Northern Wadden Sea. - Neth. J. Sea Res. 16, 389-402.

Asmus, R., 1984. Benthische und pelagische Primärproduktion und Nährsalzbilanz - Eine Freilanduntersuchung im Watt der Nordsee. - Ber. Inst. Meeresk. Kiel 131, 1-148.

Banse, K., Nichols, F. H. \& May, D. R., 1971. Oxygen consumption by the seabed III. On the role of macrofauna at three stations. - Vie Milieu (Suppl.) 22, 31-52.

Baumfalk, Y. A., 1979. On the pumping activity of Arenicola marina. - Neth. J. Sea Res. 13, 422-427.

Beukema, J. J., 1974. Seasonal changes in the biomass of the macrobenthos of a tidal flat area in the Dutch Wadden Sea. - Neth. J. Sea Res. 8, 94-107.

Beukema, $J$ J., 1976. Biomass and species richness of macro-benthic animals living on the tidal flat of the Dutch Wadden Sea, - Neth. J. Sea Res. 10, 236-261.

Beukema, J. J., 1981. Quantitative data on the benthos of the Wadden Sea proper. In: Invertebrates of the Wadden Sea. Ed. by N. Dankers, H. Kühl \& W. J. Wolff. Balkema, Rotterdam, 134-142. (Rep. Wadden Sea Working Group. 4.).

Boysen-Jensen, P., 1919. Valuation of the Limfjord I. Studies on the fish food in the Limfjord. 1909-1917. - Rep. Dan. biol. Stn 26, 1-44.

Branch, G. M. \& Branch, M. L. 1980. Competition in Bembicium auratum (Gastropoda) and its effect on microalgal standing stock in mangrove muds. - Oecologia 46, 106-114. 
Brockmann, C., 1950. Die Watt-Diatomeen der schleswig-holsteinischen Westküste. - Abh. senckenb. naturf. Ges. 478, 5-26.

Cadée, G. C., 1980. Reappraisal of the production and import of organic carbon in the western Wadden Sea. - Neth. J. Sea Res. 14, 305-322.

Cadée, G. C. \& Hegeman, J, 1974 a. Primary production of phytoplankton in the Dutch Wadden Sea. - Neth. J. Sea Res. 8, 240-259.

Cadée, G. C. \& Hegeman, J., 1974b. Primary production of the benthic microflora living on tidal flats in the Dutch Wadden Sea. - Neth. J. Sea Res. 8, 260-291.

Cadée, G. C. \& Hegeman, J., 1979. Phytoplankton primary production, chlorophyll and composition in an inlet of the western Wadden Sea. - Neth. J. Sea Res. 13, 224-241.

Colijn, F. \& Buurt, G. van, 1975. Influence of light and temperature on the photosynthetic rate of marine benthic diatoms. - Mar. Biol. 31, 209-214.

Colijn, F. \& Koeman, R., 1975. Das Mikrophytobenthos der Watten, Strände und Riffe um den Hohen Knechtsand in der Wesermündung. - Jber. ForschSt. Norderney 26, 53-83.

Colijn, F. \& Dijkema, K. S., 1981. Species composition of benthic diatoms and distribution of chlorophyll a on an intertidal flat in the Dutch Wadden Sea, - Mar. Ecol. Prog. Ser. 4, 9-21.

Colijn, F. \& Jonge, V. N. de, 1984. Primary production of microphytobenthos in the Ems-Dollard estuary. - Mar. Ecol, Prog. Ser. 14, 185-196.

Connor, M. S., Teal, J. M. \& Valiela, I., 1982. The effect of feeding by mud snails, Iyanassa obsoleta (Say), on the structure and metabolism of a laboratory benthic algal community. - J. exp. mar. Biol. Ecol. 65, 29-45.

Darley, W. M., Montague, C. L., Plumley, F. G., Sage, W. W. \& Psalidas, A. T., 1981. Factors limiting edaphic algal biomass and productivity in a Georgia salt marsh. - J. Phycol. 17, 122-128.

Davis, M. W. \& Lee II., H., 1983. Recolonization of sediment-associated microalgae and effects of estuarine infauna on microalgal production. - Mar. Ecol. Prog. Ser. 11, 227-232.

Day, J. W., Day, R. H., Barreiro, M. T., Ley-Lou, F. \& Madden, C. J., 1982. Primary production in the Laguna de Terminos, a tropical estuary in the Southern Gulf of Mexico. - Oceanologica Acta 5 (Suppl.) 269-276.

Dörjes, J., 1978. Sedimentologische und faunistische Untersuchungen an Watten in Taiwan II. Faunistische und aktuopaläontologische Studien. - Senckenberg. marit. 10, 117-143.

Duff, S. \& Teal, J. M., 1965. Temperature change and gas exchange in Nova Scotia and Georgia saltmarsh muds. - Limnol. Oceanogr. 10,67-73.

Edler, L., 1979. Recommendations on methods for marine biological studies in the Baltic Sea. Phytoplankton and chlorophyll. - Baltic mar. Biologists Publ. 5, 1-38.

Es, F. B. van, 1982. Community metabolism of intertidal flats in the Ems-Dollard estuary, - Mar. Biol. 66, 95-108.

Fenchel, T. \& Kofoed, L. H., 1976. Evidence for exploitative interspecific competition in mud snails (Hydrobiidae). - Oikos 27, 367-376.

Gieskes, W. W. C. \& Kraay, G. W., 1975. The phytoplankton spring bloom in Dutch coastal waters of the North Sea. - Neth. J. Sea Res. 9, 166-196.

Hargrave, B. T., 1969. Similarity of oxygen uptake by benthic communities. - Limnol. Oceanogr. 14, 801-805.

Hargrave, B. T., 1970. The effect of a deposit-feeding amphipod on the metabolism of benthic microflora. - Limnol. Oceanogr. 15, 21-30.

Hargrave, B. T., 1971. An energy budget for a deposit-feeding amphipod. - Limnol. Oceanogr. 16, 99-103.

Hargrave, B. T., 1972. Aerobic decomposition of sediment and detritus as a function of particle surface area and organic content. - Limnol. Oceanogr. 17, 583-596.

Hickman, M. \& Round, F. E., 1970. Primary production and standing crops of epispammic and epipelic algae. - Br. phycol. J. 5, 247-255.

Hoek, C, van den, Admiraal, W., Colijn, F. \& de Jonge, V. N., 1979. The role of algae and seagrasses in the ecosystem of the Wadden Sea: a review. In: Flora and vegetation of the Wadden Sea. Ed. by W. J. Wolff. Balkema, Rotterdam, 9-118. (Rep. Wadden Sea Working Group. 3.)

Hughes, R. N., 1970. An energy budget for a tidal flat population of the bivalve Scrobicularia plana (Da Costa). - J. Anim. Ecol. 39, 357-370. 
Jansson, B. O. \& Wulff, F., 1977. Ecosystem analysis of a shallow sound in the northern Baltic - a joint study by the Askö group. - Contr. Askö Lab. 18, 1-160.

Jansson, A.-M. Kautsky, N., Oertzen, J.-A. von, Schramm, W., Sjöstedt, B., Wachenfeld, T. von \& Wallentinus, 1., 1982. Structural and functional relationships in a southern Baltic Fucus ecosystem. - Contr. Askö Lab. 28, 1-95.

Jensen, K. \& Siegismund, H. R., 1980. The importance of diatoms and bacteria in the diet of Hydrobia-species. - Ophelia (Suppl.) 1, 193-199.

Jonge, V. N. de \& Postma, H., 1974. Phosphorous compounds in the Dutch Wadden Sea. - Neth. J. Sea Res. 8, 139-153.

Kofoed, L. H., 1975. The feeding biology of Hydrobia ventrosa Montagu. II. Allocation of the components of the carbon-budget and the significance of the secretion of dissolved organic material. - J. exp. mar. Biol. Ecol. 19, 243-256.

Kuenzler, E. J., 1961. Structure and energy flow of a mussel population in a Georgia salt marsh. Limnol. Oceanogr. 6, 191-204.

Kuipers, B. R., Wilde, P. A. W. J. de \& Creutzberg, F., 1981. Energy flow in a tidal flat ecosystem, Mar. Ecol. Prog. Ser. 5, 215-221.

Leach, J. H., 1970. Epibenthic algal production in an intertidal mudflat. - Limnol. Oceanogr. 15, $1020-1032$

Lindeboom, H. J. \& Bree, B. H. H. de, 1982. Daily production and consumption in an eelgrass (Zostera marina) community in saline Lake Gravelingen: discrepancies between the $\mathrm{O}_{2}$ and ${ }^{14} \mathrm{C}$ method. - Neth. J. Sea Res. 16, 362-379.

Linke, O., 1939. Die Biota des Jadebusens. - Helgoländer wiss. Meeresunters. 1, 201-348.

Macnae, W. \& Kalk, M., 1962. The fauna and flora of sand flats at Inhaca island, Moçambique. $-J$. Anim. Ecol. 31, 93-128.

Mann, K. H., 1965. Energy transformations by a population of fish in river Thames. - J. Anim. Ecol. $34,253-275$.

Mann, K. H., 1982. Ecology of coastal waters - a system approach. Blackwell, Oxford, 322 pp. (Studies on ecology. 8.)

Marshall, M., Oviatt, C. A. \& Skauen, D. M., 1971. Productivity of the benthic microflora of shoal estuarine environments in Southern New England. - Int. Revue ges. Hydrobiol. 56, 947-956.

Mathias, J. A., 1971. Energy flow and secondary production of the amphipods Hyalella azteca and Crangonyx richmondensis occidentalis in Marion Lake, British Columbia. - J. Fish. Res. Bd Can. 28, 711-726.

Miller, R. J. \& Mann, K. H., 1973. Ecological energetics of the seaweed zone in a marine bay on the Atlantic coast of Canada. III. Energy transformations by sea urchins. - Mar. Biol. 18, 99-114.

Nichols, F. H., 1972. A carbon and energy budget for the numerically dominant macroinvertebrate Pectinaria californiensis Hartmann, in Puget Sound, Washington, with reference to the larger, rarer coexisting species. Ph. D. thesis, Univ. Wash, Seattle, $164 \mathrm{pp}$.

Nixon, S. W., Oviatt, C. A. \& Hale, S. S., 1976. Nitrogen regeneration and the metabolism of coastal marine bottom communities. In: The role of terrestrial and aquatic organisms in decomposition processes. Ed. by J. M. Anderson \& A. Macfayden. Blackwell, Oxford, 269-283.

Nixon, S. W., Kelly, J. R., Furnas, B. N., Oviatt, C. A. \& Hale, S. S., 1980. Phosphorous regeneration and metabolism of coastal marine bottom communities. In: Marine benthic dynamics. Ed. by K. R. Tenore \& B. C. Coull. Univ. South Carolina Press, Columbia, 219-242.

Odum, E. P., 1961. The role of tidal marshes in estuarine production. - N. Y. St. Conserv. 15, 12-15.

Odum, E. P., 1980. Grundlagen der Okologie, Thieme, Stuttgart, 1-2, 1-836.

Odum, E. P. \& Smalley, A. E., 1959. Comparison of population energy flow of a herbivorous and a deposit-feeding invertebrate in a salt-marsh ecosystem. - Proc. natn. Acad. Sci. U.S.A. 45, $617-622$.

Odum, W. E. \& Heald, E. J., 1972. Trophic analysis of an estuarine mangrove community, - Bull. mar. Sci. 22, 671-738.

Odum, W. E. \& Heald, E. J., 1975. The detritus based food web of an estuarine mangrove community. In: Estuarine research. Ed. by L. E. Cronin. Acad, Press, New York, 1, 265-286.

Pace, M. L., Shimmel, S. \& Darley, W. M., 1979. The effect of grazing by a gastropod, Nassarius obsoletus, on the benthic microbial community of a salt marsh mudflat. - Estuar. coast. mar. Sci. $9,121-134$. 
Paine, R. T., 1971. Energy flow in a natural population of the herbivorous gastropod Tegula funebralis. - Limnol. Oceanogr. 16, 86-98.

Pamatmat, M. M., 1968. Ecology and metabolism of a benthic community on an intertidal sandflat. Int. Revue ges. Hydrobiol. 53, 211-298.

Pamatmat, M. M., 1975. In situ metabolism of benthic communities. - Cah. Biol. mar. 16, 613-633.

Pamatmat, M. M., 1977. Benthic community metabolism: A review and assessment of present status and outlook. In: Ecology of marine benthos. Ed. by B. C. Coull. Univ. South Carolina Press, Columbia, 89-111.

Pamatmat, M. M. \& Banse, K., 1969. Oxygen consumption by the seabed II. In situ measurements to a depth of $180 \mathrm{~m}$. - Limnol. Oceanogr. 14, 250-259.

Pilson, M. E. Q., Oviatt, C. A. \& Nixon, S. W., 1979. Annual nutrient cycles in a marine microcosm. Symposium on microcosms in ecological research, Savannah River Ecological Laboratory, DOE Symposium Series 52, 753-778.

Pollack, H., 1979. Populationsdynamik, Produktivität und Energiehaushalt des Wattwurmes Arenicola marina (Annelida Polychaeta). - Helgoländer wiss. Meeresunters. 32, 313-358.

Pomeroy, L. R., 1959. Algal productivity in salt marshes of Georgia. - Limnol. Oceanogr. 4, 386-397.

Pomeroy, L. R, 1960. Primary productivity of Boca Ciega Bay Florida. - Bull. mar. Sci. Gulf Caribb. $10,1-10$.

Pomeroy, L. R. \& Wiegert, R, G., 1981. The ecology of a salt marsh. Springer, New York, $271 \mathrm{pp}$. (Ecological studies. 38).

Pomroy, A. J., Joint, I. R. \& Clarke, K. R., 1983. Benthic nutrient flux in a shallow coastal environment. - Oecologia 60, 306-312.

Postma, H. \& Rommets, J. W., 1970. Primary production in the Wadden Sea, - Neth. J. Sea Res. 4, $470-493$.

Propp, M. V., Tarasoff, V. G., Cherbadgi, I. I. \& Lootzik, N. V., 1980. Benthic-Pelagic oxygen and nutrient exchange in a coastal region of the Sea of Japan. In: Marine benthic dynamics. Ed. by K. R. Tenore \& B. C. Coull. Univ. South Carolina Press, Columbia, 265-284.

Raalte, C. D. van, Valiela, I. \& Teal, J. M., 1976. Production of epibenthic salt marsh algae: light and nutrient limitation. - Limnol. Oceanogr. 21, 862-872.

Race, M. S., 1982. Competitive displacement and predation between introduced and native mud snails. - Oecologia 54, 337-347.

Rasmussen, M. B., Henriksen, K. \& Jensen, A., 1983. Possible causes of temporal fluctuations in primary production of the microphytobenthos in the Danish Wadden Sea. - Mar. Biol. 73, $109-114$.

Reise, K., 1978. Experiments on epibenthic predation in the Wadden Sea. - Helgoländer wiss. Meeresunters. 31, 55-101.

Reise, K., 1981 a. High abundance of small zoobenthos around biogenic structures in tidal sediments of the Wadden Sea. - Helgoländer Meeresunters, 34, 413-425.

Reise, K., 1981 b. Okologische Experimente zur Dynamik und Vielfalt der Bodenfauna in den Nordseewatten. - Verh. dt. zool. Ges. 74, 1-15.

Reise, K., 1982. Long-term changes in the macrobenthic invertebrate fauna of the Wadden Sea: Are polychaetes about to take over? - Neth. J. Sea Res. 16, 29-36.

Ryther, J. H., 1969. Photosynthesis and fish production in the sea. - Science, N. Y. 166, 72-76.

Schöttler, U., 1980. Der Energiestoffwechsel bei biotopbedingter Anaerobiose: Untersuchungen an Anneliden. - Verh. dt. zool. Ges. 73, 228-240.

Smith, R. C. Jr, Burns, K. A. \& Teal, J. M., 1972. In situ respiration of benthic communities in Castle Harbour, Bermuda. - Mar. Biol. 12, 196-199.

Taasen, J. P. \& Høisaeter, T., 1981. The shallow-water soft-bottom benthos in Lindaspollene, western Norway. 4. Benthic marine diatoms, seasonal density fluctuations, - Sarsia 66, 293-316.

Teal, J. M., 1962. Energy flow in the salt marsh ecosystem of Georgia. - Ecology 43, 614-624.

Teal, J. M. \& Kanwisher, K, 1961. Gas exchange in a Georgia salt marsh. - Limnol. Oceanogr. 6, 389-399.

Warwick, R. M. \& Price, R., 1975. Macrofauna production in an estuarine mudflat. - J. mar. biol. Ass. U. K. $55,1-18$.

Wieser, W. \& Kanwisher, J, 1961. Zoological and physiological studies on marine nematodes from a small salt marsh near Woods Hole, Massachusetts. - Limnol. Oceanogr. 6, 262-270. 
Witte, J, IJ. \& Zijlstra, J. J, 1984. The meiofauna of a tidal flat in the western part of the Wadden Sea and its role in the benthic ecosystem. - Mar. Ecol. Prog. Ser. 14, 129-138.

Wilde, P. A. W. J. de, 1980. Dynamics and metabolism of the benthos of the Wadden Sea. Hydrobiol. Bull. 14, 216-218.

Winberg, G. G. (Ed.), 1971. Methods for the estimation of production of aquatic animals. Acad. Press, London, $175 \mathrm{pp}$.

Wohlenberg, E., 1937. Die Wattenmeer-Lebensgemeinschaften im Königshafen von Sylt.-- Helgoländer wiss. Meeresunters. 1, 1-92.

Wolff, W. J. \& Wolf, L. de, 1977. Biomass and production of zoobenthos in the Grevelingen Estuary, the Netherlands. - Estuar. coast. mar. Sci. 5, 1-24.

Zeitzschel, B., 1981. Field experiments on benthic ecosystems. In: Analysis of marine ecosystems. Ed. by A. R. Longhurst. Acad. Press, London, 607-625.

Zeitzschel, B. \& Davies, J, M., 1978. Benthic growth chambers. - Rapp. P.-v. Réun. Cons. int. Explor. Mer $173,31-42$. 